\title{
Comparative study of potential transfer of natural and anthropogenic cadmium to plankton communities in the North-West African upwelling
}

\author{
Auger Pierre-Amael ${ }^{1 \stackrel{*}{-}}$, Machu Eric ${ }^{1,4}$, Gorgues Thomas ${ }^{1,4}$, Grima Nicolas ${ }^{3,4}$, Waeles Mathieu ${ }^{2,4}$ \\ ${ }^{1}$ UBO, IRD, IFREMER, LPO,UMR 6523,CNRS, F-29280 Plouzane, France. \\ 2 UBO, IRD, Lab Environm Mario LEMAR, UMR 6539,CNRS, F-29280 Plouzane, France. \\ ${ }^{3}$ CNRS, France \\ ${ }^{4}$ Ifremer, France \\ * Corresponding author : Pierre Amael Auger, tel.: + 33298498662 ; \\ email address : pierreamael.auger@gmail.com
}

\begin{abstract}
:
A Lagrangian approach based on a physical-biogeochemical modeling was used to compare the potential transfer of cadmium (Cd) from natural and anthropogenic sources to plankton communities (Cd-uptake) in the NorthWest African upwelling. In this region, coastal upwelling was estimated to be the main natural source of $\mathrm{Cd}$ while the most significant anthropogenic source for marine ecosystem is provided by phosphate industry. In our model experiment, Cd-uptake (natural or anthropogenic) in the North-West African upwelling is the result of an interplay between the $\mathrm{Cd}$ dispersion (by advection processes) and the simulated biological productivity. In the Moroccan waters, advection processes limit the residence time of water masses resulting in a low natural $\mathrm{Cd}$-uptake by plankton communities while anthropogenic Cd-uptake is high. As expected, the situation is reversed in the Senegalo-Mauritanian upwelling where natural $\mathrm{Cd}$-uptake is higher than anthropogenic $\mathrm{Cd}$-uptake. Based upon an estimate of $\mathrm{Cd}$ sources, our modeling study shows, unexpectedly, that the anthropogenic signal of potential Cdbioaccumulation in the Moroccan upwelling is of the same order of magnitude as the natural signal mainly present in the Senegalo-Mauritanian upwelling region. A comparison with observed Cd levels in mollusk and fishes, which shows overall agreement with our simulations, is confirming our estimates.
\end{abstract}

\section{Highlights}

- We model the physical-biogeochemical dynamics in the North-West African upwelling. We model the transport of cadmium from natural and anthropogenic sources. We derive proxies of potential cadmium absorption and bioaccumulation in the plankton food chain. The anthropogenic signal off Morocco at least equals the natural upwelling signal off Mauritania. We compare our results with observed cadmium levels in mollusks and fishes. 
Keywords : Cadmium, North-West African upwelling, Phosphate industry, Dispersion, Bioaccumulation, Plankton ecosystem

Abbreviations

- NW, North-West;

- Cd, cadmium;

- EBUS, Eastern Boundary Upwelling Systems;

- CCS, Canary Current System;

- CanC, Canary Current;

- CanUC, Canary Upwelling Current;

- 3D, three-dimensional;

- ROMS, Regional Oceanic Modeling System;

- GEBCO, General Bathymetric Chart of the Oceans;

- CFSR, Climate Forecast System Reanalysis 


\section{Introduction}

As much as $40 \%$ of the world's population now lives within $100 \mathrm{~km}$ of the shoreline (Martínez et al., 2007) and this population continues to grow, increasing our reliance and impact on the coastal ocean. Although eastern boundary upwelling systems (EBUS) represent less than $1 \%$ of the global area of the ocean, they represent the most productive regions around the world contributing to about $11 \%$ of the global oceanic new primary production (Carr, 2001; Carr and Kearns, 2003) and $20 \%$ of the global fish catch (Fréon, 2009). At the same time, urbanization and industrial development have a negative effect on the quality of coastal waters (Shahidul Islam and Tanaka, 2004) with a threat of amplification by global warming (Parry et al., 2007), thereby posing potential health hazards on humans (Fleming et al., 2006).

Morocco is the second phosphate producer in the world. 27 millions tons of phosphate ores are extracted and processed annually (“Annual Report, Office Chérifien des Phosphates, Maroc,” 2012) to produce phosphoric acid and phosphorus-based fertilizers. The production of phosphoric acid basically results from the chemical reaction between sulphuric acid and phosphate ores. During the reaction, calcium sulphate called phosphogypsum, is produced and spread out into the ocean. Phosphogypsum are particles containing significant abundance of crustal elements as heavy metals (the most toxic being mercury and cadmium; see list in Gaudry et al. (2007)). Thus, the Moroccan phosphate industry releases large amounts of heavy metals, particularly cadmium (Cd), in the North-West (NW) African upwelling around Safi and Jorf-Lasfar $\left(33^{\circ} \mathrm{N}\right)$. Locally, these are responsible for a significant contamination of molluscs communities (Banaoui et al., 2004; Benbrahim et al., 2006; Chafik et al., 2001; Cheggour et al., 1999; Gaudry et al., 2007; Maanan, 2008, 2007). As a consequence, mussels for instance are considered unfit for human consumption in this region (Moustaid et al., 2005). Phosphate industry is also present though less developed in Mauritania and Senegal.

Nutrient-like profiles of Cd observed in the ocean indicate its uptake by phytoplankton at the surface (Boyle et al., 1976; Morel and Price, 2003; Ripperger et al., 2007; Yeats et al., 1995). Cd is then transferred to zooplankton grazers and upper trophic levels through dietary pathways, and finally ends up in the pool of sinking organic detritus from which $\mathrm{Cd}$ is remineralized by heterotrophic bacteria. Some heavy metals are also recognized to bioaccumulate in the marine food chain (Bryan, 1984; Kennish, 1997; Wang, 2002) which could also be the case for Cd although not yet proven. This effect could magnify fish contamination. Moreover such cycle, apart from a potential bioaccumulation in fishes, may also include an accumulation of $\mathrm{Cd}$ at the sediment interface through sedimentation of organic detritus and a potential release to the water column through oxic mineralization processes (Gobeil et al., 1987). The mechanisms driving phytoplankton Cd absorption are yet poorly known (Finkel et al., 2007; Horner et al., 2013; Morel and Price, 2003; Twining and Baines, 2013). Hence, the explicit representation of the Cd cycle in biogeochemical models would be rather arbitrary. Only one biological function has been clearly identified for Cd: the potential use of $\mathrm{Cd}$ (along with zinc) in carbonic anhydrase which enters the photosynthetic machinery in marine diatoms (Lane et al., 2005; Park et al., 2007; Xu et al., 2008). However, despite the lack of known uptake processes, laboratory experiments have shown that the Cd-uptake by phytoplankton occurs in direct proportion to dissolved Cd concentrations (Sunda, 2012; Twining and Baines, 2013). Moreover, Wang and Dei (2001) report exponentially increasing rate of metal uptake with phytoplankton growth rate. As an explanation, they mention luxury uptake and storage of several trace metals as observed in regions of high concentrations like upwelling regions (see review in Horner et al. (2013). A fair statement would be that despite high uncertainty about the driving processes, Cd does enter the trophic chain depending on its concentration in seawater and 
local primary production.

Wind-driven upwelling takes place all along the NW African coast at the eastern boundary of the North Atlantic subtropical gyre following the meridional migration of the atmospheric pressure systems. It occurs mainly in summer in northern Morocco, all year round (though more intense in summer) in southern Morocco, and in winter and spring south of Cape Blanc in the SenegaloMauritanian region (see Fig. 1; Mittelstaedt, 1991; Wooster et al., 1976). Coastal upwelling induces an equatorward baroclinic coastal jet arising from the geostrophic adjustment of the surface density gradient between cold upwelled coastal waters and warmer open ocean waters (Allen, 1973). Upwelling-induced vertical motions generally occur within the 0-100 km coastal band as estimated from the Rossby radius of deformation in the NW African region (Chelton et al., 1998), so the coastal jet is confined nearshore. Offshore, the background circulation is mainly driven by the eastern branch of the North Atlantic subtropical gyre. The Canary Current, seen as a natural extension of the zonal Azores Current (Mason et al., 2012; Sala et al., 2013; Stramma, 1984), flows southward along the NW African coast before feeding the North Equatorial Current. North of Cape Blanc $\left(21^{\circ} \mathrm{N}\right)$, the Canary Current System (CCS) is thus composed of the Canary Current (CanC) and the Canary Upwelling Current (CanUC) (Mason et al., 2011). South of Cape Blanc, a cyclonic recirculation drives a poleward circulation opposed to the coastal upwelling jet (Mittelstaedt, 1991). The convergence of the water masses transported by the subtropical gyre and the recirculation gyre finally takes place in the Cape Verde Frontal Zone (Zenk et al., 1991) off Cape Blanc as attested by in situ and satellite observations (e.g. Lathuilière et al., 2008; Van Camp et al., 1991).

In this study, we aim at providing information on the fate of natural and anthropogenic Cd in plankton communities off NW Africa using a comparative modeling approach. We first detail our methodology which uses Lagrangian trajectories for drawing spatio-temporal maps of Cddispersion from the major $\mathrm{Cd}$ sources (i.e. Cd-rich waters naturally upwelled and phosphate industry). The potential uptake and bioaccumulation of natural and anthropogenic $\mathrm{Cd}$ in the plankton food chain are then compared assuming a phytoplankton Cd-uptake driven by the Cd concentration in seawater and primary production. The final goal is to gain insight on the biotic/abiotic processes influencing the Cd levels observed in marine resources of the NW African upwelling region.

\section{Methodology}

\subsection{Coupled physical-biogeochemical simulation}

The circulation of water masses is provided by the three-dimensional (3D) primitive equations, sigma-coordinates, free surface Regional Oceanic Modeling System (ROMS - (Shchepetkin and McWilliams, 2005) configured for the NW African upwelling system (Machu et al., 2009; Marchesiello and Estrade, 2009). Model parameterizations, including a parameterization of the Mediterranean outflow, are described by Marchesiello et al. (2003 \& 2009). The topography was based on GEBCO 1' resolution (General Bathymetric Chart of the Oceans, http://www.gebco.net). A "child" grid focused on the NW African upwelling $\left(10^{\circ} \mathrm{N}-35^{\circ} \mathrm{N} / 23^{\circ} \mathrm{W}-9^{\circ} 20^{\prime} \mathrm{W}, 1 / 12^{\circ}\right.$, eddyresolving) is embedded in a lower resolution "parent" grid $\left(5^{\circ} \mathrm{N}-40^{\circ} \mathrm{N} / 30^{\circ} \mathrm{W}-5.5^{\circ} \mathrm{W}, 1 / 4^{\circ}\right)$ through a two-way coupling (AGRIF - Debreu et al., 2012). Both, parent and child grids, share the same number of vertical levels : 32. The use of this technique limits the influence of discontinuities 
emerging from low spatio-temporal resolution of open boundary conditions on the "child" solution, and also produces upscaling effects on the "parent" solution.

The physical model was coupled to a biogeochemical model (PISCES - Aumont and Bopp, 2006; Aumont et al., 2003) which simulates plankton productivity and carbon biomass based upon the main nutrients (nitrate, ammonium, phosphate, silicate and iron). This model includes two size classes of phytoplankton (nanoflagellates and diatoms), zooplankton (ciliates and copepods) and detritus (the latter differ by their sinking velocity: $5 / 30 \mathrm{~m}^{-1}{ }^{-1}$ for small/large particulate material, respectively). Phytoplankton growth depends on light, temperature and the external availability in nutrients. Diatoms differ from nanoflagellates by their silicate requirement, higher requirement in iron (Sunda and Huntsman, 1997) and higher half-saturation constant due to larger size. In our simulation, microphytoplankton contribution to phytoplankton biomass is maximum in the nearshore region while nanophytoplankton biomass dominates offshore as classicaly observed in coastal upwelling regions (Blasco et al., 1980; Margalef, 1978; Nave et al., 2001) and along upwelling filaments (Cape Ghir, García-Muñoz et al., 2005; Cape Juby, Arístegui et al., 2004). This reflects the efficiency of large cells in taking up most of the upwelled new nutrients, and of small cells in better maintaining growth under nutrient limitation (higher surface-to-volume ratio). Microzooplankton differs from mesozooplankton by food diet (related to the prey/predator size ratio), grazing rates and mortality parameterization. PISCES has previously been used in global (e.g. Aumont and Bopp, 2006; Aumont et al., 2003), basin-scale (e.g. Gorgues et al., 2010; José et al., 2014) and regional upwelling studies (e.g. Echevin et al., 2008).

In the present work, a multi-decadal hindcast was run over the period 1980-2009 using interannual atmospheric forcings and consistent oceanic boundary conditions. Heat, solar and water fluxes from the CFSR atmospheric reanalysis $\left(0.3^{\circ}\right.$ resolution, NCEP Climate Forecast System Reanalysis, (Saha et al., 2010) were used to force our simulation at a 6-hour time scale. Lateral open boundary conditions of both physical and biogeochemical fields were provided by a 5 days archived NEMOPISCES simulation of the North-Atlantic basin ( $1 / 4^{\circ}$ resolution, T. Gorgues, pers. comm.). Surface nutrient fertilization is only due to iron dust deposition (climatology of an atmospheric chemistry simulation, see Aumont et al. (2008).

\subsection{Lagrangian experiments}

The ARIANE Lagrangian tool was used to simulate the trajectory of passive particles based on 3D current fields from the physical model (http://www.univ-brest.fr/lpo/ariane, (Blanke and Raynaud, 1997). Trajectories were calculated off-line from 1 day average $3 D$ velocity fields such that synoptic scales of ocean-atmosphere variability can be accurately resolved. Lagrangian calculations are done with a purely advective scheme. Hence horizontal and vertical diffusion are not accounted for. Unlike the Eulerian approach, the Lagrangian approach is able to provide informations on the biotic/abiotic history of particles. The ARIANE tool has been used successfully to derive relevant information about global, basin (Blanke et al., 1999) and regional scales of the circulations (Sala et al., 2013), as well as of larval migration patterns (Blanke et al., 2009; Bonhommeau et al., 2009; Pous et al., 2010).

A serie of tracking particle simulations was carried out for different initial conditions which depend on the Cd-sources considered (phosphate industry and upwelling). The term "particle" is used to describe anything neutrally buoyant and passively advected by the currents. In this study, it represents water parcels initially rich in dissolved Cd (hereafter "Cd-rich water parcels"). Releases of Lagrangian particles were repeated monthly over the period 1980-2008. Particles were released 
the 15 of each month and then tracked for 365 days.

For each simulation, the dispersion plume of Cd-rich water parcels was assessed by counting the number of particles passing in each cell of the $1 / 12^{\circ}$ child grid along their trajectory and by normalizing this counter by the number of released particles $(\%$, so called "Cd-dispersion" diagnostic). Additionaly, primary and secondary productions were followed along each trajectory of Cd-rich water parcels in order to build proxies of potential uptake and bioaccumulation of Cd by plankton communities.

First, a proxy for "Cd-uptake" was defined by integrating the primary production (PP in mgC $\mathrm{m}^{-3}$ day $^{-1}$ ) associated to particles passing by each grid cell $(i, j)$. The result is then normalized by the number of released particles:

$$
C d-\operatorname{uptake}(i, j)=\frac{\sum_{\text {particles }} \sum_{\text {day }=1}^{365} P P(\text { particle }, \text { day }, i, j)}{\text { Number of particles }}, P P(\text { particle,day, } i, j)=0 \text { if the particle is }
$$

not located in the cell $(i, j)$ at the time (day). This diagnostic is based on the assumption that Cduptake by plankton depends at first order on the photosynthetic fixation of carbon by phytoplankton (Morel and Price, 2003), and may inform on the potential locations where Cd has the highest probability to be absorbed by phytoplankton given the dispersion pattern of Cd-rich water parcels.

Second, a first order proxy for potential "Cd-bioaccumulation” was defined considering that the combined effect of phytoplankton absorption and zooplankton feeding may condition the bioaccumulation of $\mathrm{Cd}$ in the pelagic trophic chain. Along each trajectory, the cumulated sum of

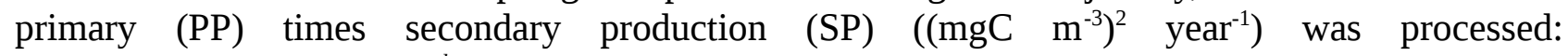
CumPS $($ particle, day $)=\sum_{d=1}^{d a y} P P($ particle,$d) * S P($ particle,$d)$. The contribution of all trajectories were then summed over the model domain and normalized by the number of released particles:

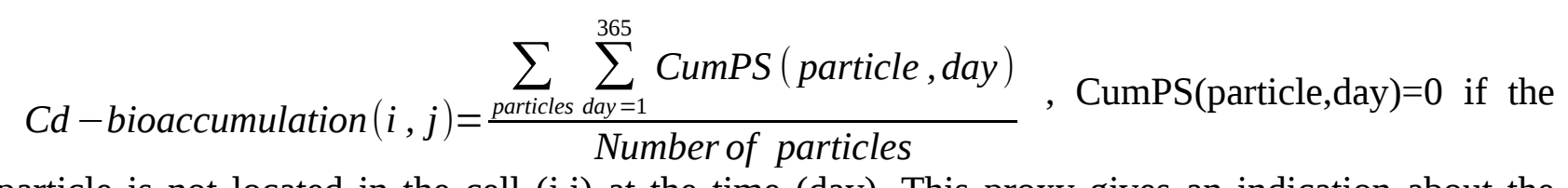

particle is not located in the cell (i,j) at the time (day). This proxy gives an indication about the regions where $\mathrm{Cd}$ has a potentiality to transfer or bioaccumulate along the plankton food chain or in the higher trophic levels as a result of advection processes and plankton productivity. Finally, the average residence time of particles passing in each cell of the $1 / 4^{\circ}$ parent grid was assessed for expliciting the patterns of particle dispersion.

The natural upwelling-induced Cd-enrichment of the coastal area was simulated by releasing one particle in each grid point between 75 and $300 \mathrm{~m}$ depth in an area delimited by the 75 and $500 \mathrm{~m}$ isobaths (14500 particles). This includes the depth range of the source of the upwelled waters reported by Mittelstaedt (1983). Particles were then considered upwelled as soon as they reached the upper $30 \mathrm{~m}$ of the water column which is approximately the maximum depth of the euphotic zone in the NW African upwelling coastal zone (see Herbland et al., 1973). A diagnostic of enrichment (\%) by the "natural" upwelling was obtained by counting, in each grid cell, the number of particles reaching 30m depth after being released between 75 and $300 \mathrm{~m}$, normalized by the total number of released particles. Before Cd-rich water parcels enter the euphotic zone, light is not sufficient for efficient photosynthesis and Cd-uptake by phytoplankton is likely insignificant. In consequence, we assumed that the analysis of the dispersion of upwelled Cd-rich water parcels only 
starts when particles have been upwelled in this upper enlighten layer.

Dispersion of anthropogenic Cd loads was simulated differently by releasing particles every $1 \mathrm{~km}$ between 0 and $10 \mathrm{~m}$ depth in one grid point $(\sim 8 \times 8 \mathrm{~km})$ located nearshore at Cape Cantin in northern Morocco between Jorf-Lasfar and Safi (33 ${ }^{\circ} \mathrm{N}, 1800$ particles). The anthropogenic sources in Mauritania and Senegal have been neglected as the production of phosphoric acid is one order of magnitude lower than in Morocco. Displacing the release location closer to Safi or Jorf-Lasfar did not change our results and conclusions (not shown). In both cases (upwelling and anthropogenic sources) the number of particles was chosen to minimize the computing time while maintaining clear dispersion patterns from monthly releases. At this stage the number of particles is not yet related to a Cd concentration.

Nevertheless to assess the respective influence of natural and anthropogenic Cd sources in a quantitative manner, the $\mathrm{Cd}$ mass represented by each released particle was roughly estimated for both sources using the very few available data. Coastal upwelling brings upper intermediate water masses (75-300m; Barton et al., 1998) for which Cd concentrations were estimated to vary between 0.02 and $0.10 \mu \mathrm{mol} \mathrm{m}^{-3}$ in the eastern central Atlantic (Yeats et al., 1995). In the upwelling case, we considered this range of $\mathrm{Cd}$ concentrations and the total volume concerned by the particle release for estimating a weight ranging between 4.5 and $22 \mathrm{kgCd}$ per particle.

We quantified the anthropogenic source of Cd using the whole by-products of the phosphate industry (phosphogypsum) which are entirely released into the ocean (Gaudry et al., 2007). The current annual production for the Jorf-Lasfar/Safi area can be estimated to 5.5 Mega-tons of phosphoric acid $\left(\mathrm{P}_{2} \mathrm{O}_{5}\right.$, “Annual Report, Office Chérifien des Phosphates, Maroc," 2012) considering that phosphate fertilizers contain $\sim 50 \%$ of $\mathrm{P}_{2} \mathrm{O}_{5}$ (Metrohm Documentation, 2014). Assuming a ratio of 5 between the mass of phosphogypsum and the produced phosphoric acid in a wet processed phosphoric plant (Gruber, 2012), this corresponds to 27.5 Mega-tons of phosphogypsum produced annually. Gaudry et al. (2007) measured a Cd concentration 8.6 $\pm 0.2 \mathrm{ppm}$ in phosphogypsum from the Jorf-Lasfar area. Al-Masri et al. (2004) experiments showed that 75\% of $\mathrm{Cd}$ associated to phosphogypsum is soluble in distilled water but considering that phosphogypsum is entirely dissolved when released in seawater and the high affinity of Cd toward chloride ligands (Comans and Van Dijk, 1988), all Cd associated with phosphogypsum is expected to be actually discharged as soluble species. Thus, the $\mathrm{Cd}$ loads from this anthropogenic source to the marine environment could be estimated to 236 tons year ${ }^{-1}$. Each particle from the anthropogenic source then represents $\sim 11 \mathrm{kgCd}$.

The estimated weights for each particle upwelled or released by the phosphate industry were then multiplied by the diagnostics presented above $\left({ }^{*} \mathrm{kgCd}\right)$ to provide quantitative diagnostics (different color bars are presented in Figures 5 to 8 to account for these weights).

\section{$3 \quad$ Results}

\subsection{Model evaluation}

The general distribution of sea surface temperature (SST) in the model agrees rather well with AVHRR satellite data (1985-2009, Pathfinder v5.1, Fig. 2). However, as found by Marchesiello and Estrade (2009) and Lachkar and Gruber (2011), there is a warm/cold bias of about $1^{\circ} \mathrm{C}$ in 
offshore/nearshore SST, respectively. The coastal region of cold surface waters is notably thinner in the model. It is particularly evident off Cape Blanc and, during the winter upwelling season, off Mauritania. Overestimated wind stress in the CFSR reanalysis compared with QuickSCAT data (not shown) in the study region probably enhances the nearshore cold bias. Nevertheless, a warm bias in the monthly Pathfinder data previous to version 5.2 was systematically found in nearshore upwelling regions where high SST gradients exist (Dufois et al., 2012). At the same time, uncertainties associated with the atmospheric heat fluxes from CFSR may explain the offshore warm bias. Climatology of near-surface currents from the model (15m) and derived from satellitetracked near-surface drifting buoy (1979-present, 1/2 ${ }^{\circ}$, Lumpkin and Johnson, 2013) are also presented in Figure 2 (winter and summer averages). The general circulation and its seasonal variability are well reproduced by the model. The Azores Current is visible at the northern boundary through eastward/southward velocities in winter/summer, respectively. Maximum southward velocity is found in the coastal upwelling jet (CanUC) from Cape Cantin to Cape Blanc where upwelling occurs all year round. The signature of upwelling filaments off Cape Ghir and Cape Boujdour is clearly visible in the model as strong seaward deflections of the coastal current. Note that particularly strong westward velocities off Cape Boujdour seem to limit the drifter sampling over the Saharan Bank. Surface currents then turn west off Cape Blanc feeding the North Equatorial Current (see Fig. 1). In the Senegalo-Mauritanian region, surface currents are directed southwestward during the winter upwelling season. Alternatively, a moderate northward current (which can be seen as an extension of the North Equatorial Countercurrent, see Fig. 1) lays south of Cape Blanc both in the model and in the data during summer when upwelling-favourable winds are weak. However, this northward current does not persist during winter in our simulation as well as in the drifter climatology offshore of Mauritania. The seasonality of the coastal current in the same latitudinal band, a crucial feature, is nevertheless well simulated with strong southward advection in winter and moderate northward advection in summer.

The simulated surface chlorophyll averaged over the period 1998-2009 is consistent with SeaWiFS data (Fig. 1). Chlorophyll concentrations are maximum in the coastal upwelling (5-10 $\mathrm{mgChl} \mathrm{m}^{-3}$ ) and decrease offshore toward the subtropical gyre (0.1-0.2 $\left.\mathrm{mgChl} \mathrm{m} \mathrm{m}^{-3}\right)$. The offshore extension of the coastal chlorophyll signature increases from the Moroccan to the Senegalo-Mauritanian upwelling although the cross-shore gradient is not as sharp as in satellite observations. Moreover, nearshore chlorophyll concentrations (Fig. 1) and values of primary production (Fig. 3) are generally lower than satellite-based estimates (Carr, 2001; Gregg et al., 2003).

The seasonal variability of primary and secondary productions (Fig. 3) is also coherent with surface chlorophyll patterns from SeaWiFS data (see Lathuilière et al., 2008). In the Moroccan upwelling, peaks of plankton productivity occur in late winter around Cape Cantin $\left(33^{\circ} \mathrm{N}\right)$ and throughout summer toward Cape Ghir $\left(30^{\circ} \mathrm{N}\right)$ and Cape Juby $\left(28^{\circ} \mathrm{N}\right)$. In contrast, relaxation of Trade winds globally induces a lower production in fall (Fig. 3). Seasonal variability is less pronounced around Cape Blanc $\left(21^{\circ} \mathrm{N}\right)$. In the Senegalo-Mauritanian upwelling, plankton productivity peaks in winter/spring.

\subsection{Dispersion from the main natural and anthropogenic sources}

\subsubsection{Dispersion of upwelling loads}

The upwelling-induced enrichment of surface waters (percentage of particles reaching the depth of $30 \mathrm{~m}$ ) occurs mainly nearshore between $12^{\circ}$ and $34^{\circ} \mathrm{N}$ slightly decreasing southward (Fig. 4). In the 
Moroccan upwelling, coastal enrichment is maximum from Cape Cantin to Cape Ghir, off Cape Juby, Cape Boujdour and over the southern Saharan Bank. Local minima are found nearshore between Cape Draa and Cape Juby as well as in the northern Saharan Bank and Arguin Bank. In these latter regions where the continental shelf is large a signature of enrichment is detected along the shelf break. In the Senegalo-Mauritanian region, enrichment occurs all along the coast with a nearshore minimum off Cape Verde where the orientation of the coastline relative to wind direction is not optimum which probably limits wind-induced upwelling.

According to the seasonal migration of the Azores high (Mittelstaedt, 1991), enrichment is maximum in spring/summer and in winter/spring in the Moroccan and Senegalo-Mauritanian upwelling, respectively. This can be seen through the influence of the migration of the Azores high on the seasonal pattern of dispersion (Fig. 5). The periods of maximum upwelling in each subregion are accompanied by a minimum offshore extension of the upwelling signature (see Fig. 5). At the same time, although less intense, enrichment signature is detected offshore around the Canary Islands and off the Senegalo-Mauritanian upwelling (see Fig. 4). This is particularly true in spring/summer (see Fig. 5) when maximum wind curl in the region may enhance Ekman pumping over vast areas (Lathuilière et al., 2008).

Once upwelled into the euphotic layer, the spatial signature of dispersion from the upwelling source shows year round southward increase with maxima in the Mauritanian upwelling and off Cape Blanc within the Cape Verde Frontal Zone (Fig. 6a). A weaker signature relative to the surrounding environment generally characterizes regions with large continental shelf like the Saharan Bank and the Arguin Bank associated with low enrichment (see Fig. 4). In the Moroccan upwelling, the maximum concentration of particles is found nearshore at Cape Ghir and between Cape Juby and Cape Boujdour (Fig. 6a). It extends offshore off Cape Juby and off the Saharan Bank, particularly in winter/spring (Fig. 5). In the Mauritanian upwelling, the coastal maximum migrates from the Arguin Bank in late summer to southern Mauritania in early winter (Fig. 5), the minimum signature being found in early summer. Despite an important enrichment in winter/spring (not shown, see Fig. 4), only a weak signature is revealed south of Cape Verde (see Fig. 6a).

\subsubsection{Dispersion of anthropogenic loads}

The average dispersion of anthropogenic loads released by phosphate industry around Cape Cantin is presented in Figure 7a. All year round, these particles mainly escape the nearshore CanUC and are transported offshore in the CanC. Significant offshore transport toward the Canary Islands at Cape Juby limits the southward extension of the dispersion plume. After passing the Canary Islands, the dispersion plume is evanescent and almost disappears south of Cape Blanc. The seasonal variability of the dispersion plume is presented in Figure 8. In fall/winter, the dispersion plume is close to the coast and deflection from the coast occurs off Cape Ghir and even Cape Draa in November. At this period, the concentration of particles and their southward extension are maximum following a pathway between Lanzarote island and the continent. Near the release area, fall is characterized by a northward coastal signature. In spring/summer, the dispersion plume detaches early from the coast at Cape Sim and two distinct maxima of particles concentration are highlighted. The first maximum occurs downstream of the release area whereas the second one occurs south of Gran Canaria downstream of the Lanzarote Passage. Despite enhanced southward coastal transport by the CanUC (Barton et al., 1998), maximum westward transport leads to maximum particle load to the Canary Islands in summer. 


\subsection{Potential Cd-uptake and bioaccumulation in plankton}

As natural upwelling is a source of $\mathrm{Cd}$ and nutrients, the average patterns of potential phytoplankton Cd-uptake and Cd-bioaccumulation in the plankton trophic level (Fig. 4b \& 6c) respectively match the upwelling-induced enrichment and dispersion patterns (Fig. 3 \& 6a). The meridional gradient (increasing southward) of Cd-uptake and Cd-bioaccumulation is more intense than for Cddispersion. Maximum Cd-uptake is encountered from the southern Saharan Bank to Cape Verde and Gambia. A moderate signature of Cd-uptake is also detected along the Moroccan coast in the nearshore regions of Cape Sim/Cape Ghir and Cape Draa/Cape Juby, and further offshore over the northern Saharan Bank. Bioaccumulation also increases southward and the offshore extension is enhanced in the Mauritanian upwelling (Fig. 6c). Noteworthy, the southward increase of secondary production is more pronounced than for primary production (Fig. 3), particularly during the winter/spring upwelling season in the Senegalo-Mauritanian region. This induces a southward increase of potential Cd-bioaccumulation compared to Cd-uptake from Mauritania to Senegal.

The mean pattern of Cd-uptake of anthropogenic loads shows a maximum signature around the release area (Fig. 7b). It decreases southward but a second maximum is then found nearshore between Cape Draa and Cape Juby. The Cd-bioaccumulation pattern (Fig. 7c) spans from Cape Sim to the Canary Islands with two maxima located around the release area and south of the Canary Islands. In the Senegalo-Mauritanian upwelling, the signatures of both uptake and bioaccumulation of anthropogenic Cd released in northern Morocco are very low.

The co-localisation of Cd-uptake and Cd-bioaccumulation (related to primary and secondary productions) with Cd-dispersion is less obvious for anthropogenic load than for upwelling load as the sources of nutrients and Cd are independent in this case. In winter/spring, the maximum of phytoplankton Cd-uptake (not shown) is mainly attributed to high primary production (Fig. 2) since particle concentration is rather weak at this time of the year (Fig. 6). In contrast, low primary production is responsible for moderate signature of Cd-uptake in early fall (not shown). Minimum Cd-uptake in late spring/early summer is attributed to a decoupling between coastal primary production (Fig. 3) and offshore particle transport (Fig. 8).

The potential Cd-bioaccumulation due to anthropogenic sources is found maximum in winter/spring (not shown) from Cape Sim to the south of the Canary Islands (Fig. 7c). It results from high primary/secondary production in winter/spring respectively (Fig. 3) whereas particles exhibit their lowest concentration during this period (Fig. 8). In fact, secondary production increases from late winter to summer while primary production has stagnated (see Fig. 3). The combination of local transfer to zooplankton at the coast and maximum offshore transport by the CanC (Mason et al., 2011) then leads to a maximum signature of Cd-bioaccumulation during spring/summer in the northern Canary Islands (not shown).

\subsection{Comparative influence of natural and anthropogenic sources}

Based on our rough estimation of Cd sources, the average signature of particles concentration related to anthropogenic and natural $\mathrm{Cd}$ loads can be expressed in mass of $\mathrm{Cd}$ and compared quantitatively. Very few is known about Cd uptake and remineralization. As a first step, we put aside those uncertainties by assuming that the amount of dissolved Cd present in the water parcels transported by particles is maintained by high remineralization rates of $\mathrm{Cd}$ along their path. The implications of this assumption will be discussed later in this section.

Scenarios presented in Figure 9 show differences of weighted Cd-dispersion between anthropogenic 
and natural sources ("industry release" - "upwelling load"). Extreme scenarios assume maximum/minimum estimates for the upwelling source (scenario $\mathrm{A}$ and $\mathrm{B}$, respectively). The maximum signature of Cd-dispersion for both sources are of the same order of magnitude in scenario A ( $\sim 0.6 \mathrm{kgCd}$, Fig. 9a) whereas the anthropogenic signature $(\sim 0.6 \mathrm{kgCd})$ largely exceeds the one of upwelling ( 0.1 kgCd) in scenario B (Fig. 9b). As a consequence, in the Moroccan upwelling, the anthropogenic signature of Cd-dispersion would at least equal (Scenario A) or even exceed (Scenario B) the natural upwelling signature which is more intense in the southern part of the system. Assuming Scenario A of high weight for the upwelling source, the anthropogenic signal still dominates over upwelling in the CanC from northern Morocco to Cape Boujdour through the Canary Islands. The prevailing influence of the anthropogenic signal is less intense in spring (not shown) when the upwelling signature is maximum in the Moroccan upwelling. In contrast, the anthropogenic signal is dominated by the upwelling signal in the coastal area, except along the shore upstream of Cape Juby. However, in fall the anthropogenic signal also dominates the upwelling signal along the shore when the dispersion plume approaches the coast (Fig. 8).

Considering that the uptake of Cd by the phytoplankton occurs in direct proportion to dissolved $\left[\mathrm{Cd}^{2+}\right]$ (Sunda, 2012; Twining and Baines, 2013), we expect that Cd-bioaccumulation in the plankton communities will respond to the magnitude of natural and anthropogenic sources. Thus, the Cd-bioaccumulation from both sources can be compared quantitatively. The maximum signature of anthropogenic and natural Cd-bioaccumulation are of the same order of magnitude although spatially differentiated (Fig. 4c \& 7c). Hence, bioaccumulation of anthropogenic Cd tends to exceed bioaccumulation of $\mathrm{Cd}$ supplied by the upwelling in the northern part of the system and conversely from Cape Blanc to Senegal (Fig. 9c \& 9d). Assuming Scenario A, the anthropogenic Cdbioaccumulation consistently dominates over the natural upwelling signal in the CanC. In the coastal area, the impact of both natural and anthropogenic sources is quantitatively the same. Hence, the anthropogenic signal at least equals (Scenario A) and may significantly exceed the natural upwelling signal (Scenario B) in the coastal area of the Moroccan upwelling. Noteworthy, the anthropogenic signal is maximum in fall/winter while the natural signal is minimum (not shown).

However, these results are based on our earlier assumption that Cd-utptake and bioaccumulation were not limited by the availability of dissolved Cd due to high remineralization rates (Boyle et al., 1976; Delgadillo-Hinojosa et al., 2001). Nevertheless, a contradictory assumption can be made stating that a water parcel, originally full of $\mathrm{Cd}$, will lose its $\mathrm{Cd}$ content via the sinking of biogenic particulate matter. What would be the sensitivity of our results to these assumptions ? To address that point, we have recalculated the $\mathrm{Cd}$ diagnostics considering a loss of $\mathrm{Cd}$ along the path of particles (Fig. 10). The particulate carbon export from the water parcels are cumulated to simulate the along-path depletion of $\mathrm{Cd}$. Carbon export is then converted to phosphorus through P:C redfield ratio (1:106), and then to $\mathrm{Cd}$ with in situ measurements of $\mathrm{Cd}: \mathrm{P}\left(0.2 \pm 0.110^{-3} \mathrm{molCd}: \mathrm{molP} ; \mathrm{H}\right.$. Planquette, pers. comm.). Noteworthy, the source of $\mathrm{Cd}$ due to the sinking of particulate matter from above is ignored which may lead to overestimate the net Cd loss. Therefore, we provide two test cases : the first one with an underestimated loss in Cd (see above) and the second one with an overestimated loss of $\mathrm{Cd}$ (here). When Cd export from the water parcels is crudely taken into account, the natural signal is significantly reduced compared to the anthropogenic signal both north and south of Cape Blanc. A decoupling between the trajectory of anthropogenic Cd and primary production can explain that the anthropogenic signal is less impacted by Cd loss. 


\section{Discussion}

\subsection{Cd sources}

The Cd cycle in the ocean is a priori controlled by biogeochemical and physical processes. Because of phytoplankton uptake at the surface, sinking of organic detritus and remineralization at depth, Cd exhibits a nutrient-like behaviour in the water column (Morel and Price, 2003). In the NW African region, dissolved Cd is re-injected in the surface layer by the upwelling of subsurface waters. At global scale, the major external inputs of dissolved Cd to the ocean are atmospheric deposition and river loads (Duce et al., 1991; resp. 240-400 tons year $^{-1}$ assuming a 60\% solubilisation - Theodosi et al., 2010, and 3600 tons year $\left.{ }^{-1}\right)$. As a matter of fact, our estimation of anthropogenic annual Cd loads by phosphate industry in northern Morocco (236 tons year-1) falls in the lower range of global atmospheric loads. Noticeably, this exceeds the contribution of the largest rivers in the world (Amazon: 65 tons year ${ }^{-1}$, Boyle et al., 1976; Changjiang: 30 tons year ${ }^{-1}$, Edmond et al., 1985). Considering an average atmospheric deposition rate of $50 \mu \mathrm{gCd} \mathrm{m^{-2 }}$ year $^{-1}$ deduced from observations in northern Morocco (62 $\mu \mathrm{gCd} \mathrm{m}^{-2}$ year $^{-1}$ at Cape Spartel, Guieu et al., 2010) and the Canary Islands ( $\sim 40 \mu g C d \mathrm{~m}^{-2}$ year ${ }^{-1}$ with a sinking velocity of $1 \mathrm{~cm} \mathrm{~s}^{-1}$, Gelado-Caballero et al., 2012), we estimated atmospheric inputs into the $0-100 \mathrm{~km}$ coastal band at 8 tons year ${ }^{-1}$ off NW Africa. This input, which is essentially of anthropogenic origin with Cd being associated with small particles of non crustal origin (Gelado-Caballero et al., 2012; Guieu et al., 2010), appears to be one to two order of magnitude below those from Ekman transport or from phosphate industry effluents and has thus not been considered in our study. Moreover, deposition events do not affect the whole NW African coastline at a time meaning that our estimation is probably overestimated. Cd sediment deposition is maximum where the continental shelf is large (Fig. 11) which corresponds to regions of high residence time (Fig. 12, see caption). However, remobilisation of $\mathrm{Cd}$ from sediment is probably very limited in this area. Indeed, organic carbon-rich sediments of coastal upwelling systems extensively trap Cd as sulfides (Brumsack, 2006).

Our comparative study of natural and current anthropogenic signals in the NW African upwelling obviously depends on our estimation of Cd sources. The range of Cd concentrations estimated for upwelling source waters $(75-300 \mathrm{~m})$ is based upon Cd profiles sampled at open ocean stations in the eastern central Atlantic (Yeats et al., 1995) north of the Cape Verde Frontal Zone (see Fig. 1). Thus, no meridional gradient of Cd contents is considered for upwelling waters which may not be realistic. The Cd-depleted surface layer could be thinner approaching the region of upwelling influence. The fast remineralization of sinking particulate organic matter produced at the coast and exported offshore by Ekman transport and filaments could increase the $\mathrm{Cd}$ concentrations in upwelled water masses. This would advocate that our computation of the naturally upwelled Cd is underestimated. However, a Cd profile recently sampled close to the shelf break off Cape Boujdour (M. Waeles, pers. comm.) is very similar to those observed by Yeats et al. (1995). Moreover, our estimation is backed up by very similar results (not shown) obtained by estimating the Cd concentrations in upwelling source waters using an alternative method based upon simulated phosphate concentrations and Cd:P ratio observed in NACW $\left(0.2410^{-3} \mathrm{molCd}\right.$ :molP, Yeats et al., 1995) with our simulated phosphate concentrations falling in the range given by the World Ocean Atlas climatological product (not shown, http://www.nodc.noaa.gov/OC5/woa13).

There is also uncertainty about the estimation of the anthropogenic source. The concentration of Cd in phosphogypsum produced around the world is estimated to 1-40 ppm (Al-Masri et al., 2004). The value of Cd concentration (8.6 ppm) given by Gaudry et al. (2007) for phosphogypsum from the Jorf-Lasfar/Safi area falls in the latter range. The variability observed in processed phosphate rocks 
([Cd]=10.5-44 ppm, Gaudry et al., 2007) yet suggests a potential variation by a factor 4 . The Cd loads by phosphate industry also depend on the production of phosphoric acid which should increase in the future (“Annual Report, Office Chérifien des Phosphates, Maroc,” 2012). In consequence, the anthropogenic influence is expected to increase accordingly compared to the natural upwelling signal. Moreover, the potential increase of primary production and Cd-uptake due to phosphate loads by phosphate industry effluents is not taken into account in our work.

\subsection{Natural signal of Cd-dispersion, uptake and bioaccumulation}

The increase of natural, upwelling-induced, Cd particles from the Moroccan to the Mauritanian upwelling (Fig. 6a) is not related to enrichment variability which is quite homogeneous along the coast of NW Africa (Fig. 4). It is rather induced by the dynamical coupling which exists between the open ocean and the coastal upwelling region. Indeed, the maximum signature of Cd-dispersion from natural loads simulated off Cape Blanc (Fig. 6a) results from the convergence of northern and southern water masses in the Cape Verde Frontal Zone. In the Moroccan upwelling, both the CanC and the CanUC generally flow southward, so upwelled water masses are uniformly advected southward and fuel the Cape Blanc region. Strong advection by the CanUC limits the residence time of particles in the Moroccan upwelling (Fig. 12). The Senegalo-Mauritanian region is characterized by the presence of a permanent cyclonic circulation involving North Equatorial Countercurrent and South Atlantic Central Water (Hernández-Guerra et al., 2005) which implies northward flow at its eastern flank. The coastal upwelling jet then develops inshore of a northward flow in this region. Particles upwelled at the coast are transported offshore by filaments (Kostianoy and Zatsepin, 1996), and then northward under the influence of permanent large-scale cyclonic circulation. These dynamical features increase the residence time of particles in the Senegalo-Mauritanian upwelling compared to the Moroccan upwelling (Fig. 12). This circulation would also transport northward the particles upwelled south of Cape Verde towards the southern Mauritanian upwelling.

In the Moroccan upwelling, the maximum "natural" Cd-uptake (i.e. induced by the upwelling) occurs from Cape Sim to Cape Ghir $\left(31-32^{\circ} \mathrm{N}\right)$, from Cape Draa to Cape Boujdour $\left(26-29^{\circ} \mathrm{N}\right)$ and over the southern Saharan Bank $\left(22-24^{\circ} \mathrm{N}\right)$ (Fig. 6b). These patterns are consistent with satellite observations of surface chlorophyll biomass on the shelf (isobath $200 \mathrm{~m}$, Lathuilière et al., 2008). It is also the case for minimum Cd-uptake in the Agadir Bay $\left(30^{\circ} \mathrm{N}\right)$ and the northern Saharan Bank $\left(24-26^{\circ} \mathrm{N}\right)$. Indeed, this natural Cd-uptake depends on the combined effects of new production and advection processes which also control the build-up of phytoplankton biomass. In the Moroccan upwelling, the regions of maximum Cd-uptake are characterized by high residence time (Fig. 12) which can be attributed to shelf topography (Marchesiello and Estrade, 2009). Hence, Cd-uptake in these regions is probably due to the lack of dispersion of particle in the coastal area. This is particularly true for the nearshore area between Cape Draa and Cape Juby (Fig. 12) where in situ observations show important $\mathrm{Cd}$ concentration in particulate organic matter $(>0.45 \mu \mathrm{m}, \mathrm{H}$. Planquette, pers. comm.). Despite maximum enrichment off Cape Boujdour (Fig. 4), the minimum Cd-uptake simulated along the shore upstream of Cape Boujdour agrees with an observed discrepancy between upwelling intensity and surface chlorophyll concentrations in the northern Saharan Bank (Lathuilière et al., 2008). Water masses upwelled off Cap Boujdour appear mainly transported along the shelf break as entrained by the CanC after being exported offshore by the Cape Boujdour filament (Fig. 6a). This process results in a relative loss of upwelled nutrients and plankton biomass to the open ocean. A relative nearshore limitation of new primary production explains moderate phytoplankton biomass observed in the northern Saharan Bank (Lathuilière et al., 
2008). In the southern Saharan Bank, high phytoplankton biomass mainly results from regenerated production (not shown) which is potentialized by high residence time (Fig. 12). As a consequence, low natural Cd-bioaccumulation over the Saharan Bank (Fig. 6c) seems related to upstream offshore transport. Note that the Saharan Bank is also a region of high carbon export potentially leading to Cd storage in sediments (Fig. 11). Accumulation/resuspension processes could therefore attenuate the low Cd-bioaccumulation signal presented in this work for this area.

The southward increase of Cd uptake and bioaccumulation in the NW African upwelling is also consistent with increasing chlorophyll biomass south of the Saharan Bank $\left(26^{\circ} \mathrm{N}\right.$, Lathuilière et al., 2008). High residence time of upwelled waters in the coastal Mauritanian upwelling (Fig. 12) would support a strong build-up of phytoplankton biomass (Lachkar and Gruber, 2011) and then Cdabsorption by plankton communities. In contrast, strong offshore transport by the CanUC and filaments in the Moroccan upwelling (Fig. 12) relatively limits new production at the coast as highlighted above for the Saharan Bank. Low residence time of upwelled waters in the coastal area together with a meridional gradient of nutrient contents (see below) could explain the discrepancy observed between upwelling intensity and weak surface chlorophyll biomass in the Moroccan upwelling (Lathuilière et al., 2008), and consequently low Cd-uptake.

Secondary production appears to be relatively reinforced southward compared to primary production (Fig. 3) which means a potential increase of $\mathrm{Cd}$ transfer to zooplankton (Cdbioaccumulation). Unlike primary production, secondary production would follow the meridional gradient of nutrient concentrations in upwelled waters off NW Africa (Arístegui et al., 2009; Minas et al., 1982) in agreement with the role of integrator played by zooplankton in the functioning of the ecosystem (Drinkwater et al., 2010). South Atlantic Central Water (SACW) upwelled south of Cape Blanc is more concentrated in nutrients than the North Atlantic Central Water (NACW) upwelled north of Cape Blanc. The northward propagation of SACW along the continental slope is driven by the variability of the poleward undercurrent (Pelegrí et al., 2005) which deepens northward from Cape Verde to Cape Blanc (Binet, 1988). However, coastal in situ observations of primary production do not indicate a clear relation with a southward increase of nutrient in upwelling source waters (Arístegui et al., 2009). Instead, remarkable offshore extension of satellite-derived chlorophyll signature is observed in the Mauritanian upwelling and attributed to weak nutrient limitation during the upwelling season (Lathuilière et al., 2008) along with offshore transport by mesoscale dynamics. Lathuilière et al. (2008) suggest that upwelling-induced nutrient inputs may exceed the assimilation capacity of phytoplankton biomass at the coast. The offshore advection by Ekman transport of unconsumed nutrients at the coast would allow phytoplankton to grow further offshore. Thus, primary production occurring offshore appears to be concomitant with increasing secondary production at the coast. Our results then suggest that Cd-bioaccumulation could follow the upwelling intensity through a control of the assimilation capacity of phytoplankton biomass by secondary production.

\subsection{Anthropogenic signal of Cd-dispersion, uptake and bioaccumulation}

Dispersion of anthropogenic Cd shows striking features on its own, the most remarkable being the detachment from the nearshore productive CanUC early off Cape Ghir (Fig. 7a). In the Moroccan upwelling, offshore Ekman drift and mesoscale structures such as meanders, filaments and eddies are mainly responsible for the offshore transport of particles originally released at the coast (Arístegui et al., 2009; Barton et al., 1998). From in situ organic carbon measurements in the 
CanUC, Álvarez-Salgado et al. (2007) estimated that filaments export 2.5 to 4.5 times more carbon than Ekman transport. In particular, the Cape Ghir filament would export 2 to 3 times more carbon than the other filaments in the Moroccan upwelling, namely Cape Juby and Cape Boujdour. The Cape Ghir filament is a quasi-permanent structure clearly visible in satellite-derived products of sea surface temperature, particularly in summer when winds strengthen (e.g. Pelegrí et al., 2005). Indeed, recent process-oriented modeling study underlined the effects of the wind on the formation of filament via the injection of positive relative vorticity into the water flow (Troupin et al., 2012). The others filaments formed off Cape Juby, Cape Boujdour and Cape Blanc are also responsible for particles dispersion and strong offshore transport (Barton et al., 2004; Fischer et al., 2009). In particular, the Cape Juby filament enables a connectivity between the Moroccan coast and the Canary Islands as already evidenced by Brochier et al. (2011).

As highlighted above, filament activity is responsible for strong offshore transport of particles originally released nearshore, particularly in summer (Arístegui et al., 2009; Mittelstaedt, 1991; Wooster et al., 1976). There is also observational evidence of the strengthening of the CanC in summer and of its farther offshore positioning (Machín et al., 2006; Stramma and Siedler, 1988). These observations are consistent with model results showing maximum westward transport at this season (Fig. 8). Using an integrative modeling approach based on the latter observations, Mason et al. (2011) suggest that anomalous cyclonic structures generated by nearshore wind stress curl along the Moroccan coast and around the Canary Archipelago induce strong westward particle transport north of the Canary Islands in spring/summer.

Then, these anomalies propagate westward as baroclinic planetary (Rossby) waves which enhances the coastal recirculation of water masses in the following fall/winter. This is consistent with a maximum concentration of particles in the model from late summer to early winter (Fig. 8) which occurs simultaneously with the migration of the dispersion plume toward the coast. Near the release area, the result is a coastal signature which extends toward the north (Fig. 8). South of the Canary Islands, a cyclonic structure is responsible for minimum westward transport (Mason et al., 2011).

Finally in spring, anticyclonic/cyclonic structures which are organized meridionally, and which originate from the nearshore area in fall and propagate westward from fall to spring, probably explain the strong dispersion simulated between Cape Sim and the Canary Islands in winter/spring (Fig. 8). Similarly, the particle pathway in the Lanzarote Passage highlighted by the model in spring (Fig. 8) is related to the nearshore formation of a cyclonic loop along the Moroccan Coast at this season (Mason et al., 2011).

Along with primary production, the concentration of particles in the coastal area should drive the potential Cd-uptake by phytoplankton. The seasonal dynamics of anthropogenic Cd-dispersion simulated by our model is consistent with our knowledge of the current dynamics in the Moroccan upwelling (see above). As the seasonal variability of plankton productivity (Fig. 3) is also coherent with satellite observations (Lathuilière et al., 2008), we therefore believe the annual patterns of anthropogenic Cd-uptake and bioaccumulation by plankton communities presented in this study rely on a solid ground. Noteworthy, anthropogenic Cd-bioaccumulation is significant in the nearshore area upstream of Cape Draa and Cape Juby (Fig. 7c), particularly in fall/winter (not shown), because mesoscale recirculations limit particle dispersion in this area. Moreover, the maximum anthropogenic Cd-bioaccumulation highlighted in the northern Canary Islands during the period of maximum upwelling intensity in spring/summer results from the role of integrator played by zooplankton (see above). 


\subsection{Cd levels in marine resources}

The patterns of bioaccumulation simulated in this work do not consider the physiological processes affecting bioaccumulation of $\mathrm{Cd}$ in plankton communities. Although no general rule predicts the evolution of trace metals along a marine food-web, there is generally a decrease in classical marine food-web from phytoplankton to copepods to fish largely caused by the effective efflux of metals by copepods and a very low assimilation by fish (Bryan, 1984; Kennish, 1997; Rossi and Jamet, 2008; Ruangsomboon and Wongrat, 2006; Wang, 2002). Levels of potential Cd-bioaccumulation simulated in this work are therefore probably overestimated and the southward increase described above for the Senegalo-Mauritanian upwelling would then be moderated. Wang and Rainbow (2008) further indicate a significant interspecific and intraspecific variability of metal burden in mollucs organisms. The relationship between Cd-bioaccumulation in plankton and the contamination of upper trophic levels is obviously not direct and requires further investigation.

Along the NW African coast, low Cd levels are found in bivalve molluscs except at some hot spots in northern Morocco and southern Senegal where Cd levels exceed the limit authorized by the European Union (1 $\mu \mathrm{g} \mathrm{g}^{-1}$ wet weight, i.e. $\sim 5 \mu \mathrm{g} \mathrm{g}^{-1}$ dry weight, Commission of the European Communities, 2006). These high Cd concentrations are attributed to anthropogenic influence (i.e. phosphate industry, Banaoui et al., 2004; Cheggour et al., 1999; Maanan, 2008, 2007; Romeo et al., 2000; Sidoumou, 1991; Sidoumou et al., 2006, 1999, 1992). In the model, the anthropogenic impact in the coastal area is mainly restricted to the vicinity of the anthropogenic sources located north of Cape Sim (Fig. 7) where observed Cd levels in bivalve molluscs clearly exceed authorized limits. In agreement with observations (Banaoui et al., 2004), the anthropogenic model signature is evanescent at Cape Ghir because of strong offshore transport between Cape Sim and Cape Ghir.

Excluding local anthropogenic influence, Cd levels in molluscs are more important south of Cape Blanc (Romeo et al., 2000; Sidoumou et al., 2006, 1999, 1992). North of Cape Blanc, Cd levels peak at Cape Juby and decrease southward over the Saharan Bank (Banaoui et al., 2004; see also Sidoumou et al., 2006). This latitudinal variability of Cd levels in molluscs fairly correlates with model results of Cd-bioaccumulation due to natural upwelling along the NW African coast (Fig. 6c). Nonetheless, anthropogenic influence on observed $\mathrm{Cd}$ concentration in mollusc can not be ignored at Cape Juby (Banaoui et al., 2004) notably because mesoscale recirculations limit particle dispersion in this area.

For fish captured around the Canary Islands, off Morocco (Laâyoune) and Mauritania (Nouakchott), Cd levels are lower in muscles than in internal organs particularly liver, kidneys and spleen (El Morhit et al., 2013; Lozano et al., 2009; Romeo et al., 1999; Sidoumou et al., 2005). Metal levels in muscles reflect metal contents in the surrounding water, whereas levels in internal organs represent life-integrated metal storage (Tepe et al., 2008). Thus, respectively low/high Cd levels in muscle tissue/internal organs suggest that fish mainly lives in Cd-depleted surface waters (Yeats et al., 1995) where plankton biomass is rich in Cd. The very few available data on Cd concentration in fish suggest higher Cd levels in liver in the Mauritanian region compared to the Moroccan coast and the Canary Islands (El Morhit et al., 2013; Lozano et al., 2009; Romeo et al., 1999; Sidoumou et al., 2005). Similarly, Cd levels are higher in the Canary Islands than in the Azores Islands (Lozano et al., 2009). Model results of Cd-bioaccumulation due to natural upwelling (Fig. 6c) are therefore consistent with Cd levels in marine resources and are also in agreement with the current knowledge of the key factors driving metal bioaccumulation in marine organisms (Wang and Rainbow, 2008).

Low Cd levels observed in fish collected by commercial fisheries in the North-East Canary Islands (La Graciosa, Lanzarote, Lozano et al., 2009) suggest a weak influence of anthropogenic sources. This could be explained by a strong seasonality of the anthropogenic signature (see Fig. 8) 
compared to the upwelling signature in the Senegalo-Mauritanian region. In our experiment, the anthropogenic influence is maximum in the Lanzarote Passage and south of the Canary Islands (Fig. 7c). This may explain higher Cd levels observed in fish muscles off Morocco compared to the Canary Islands and the Mauritanian coast (El Morhit et al., 2013; Lozano et al., 2009; Romeo et al., 1999; Sidoumou et al., 2005). Our study suggests that fish living in the northern part of the Canary Islands would probably be less impacted. Nevertheless, a significant addition of Cd in the plankton component is expected from anthropogenic activities in the Moroccan upwelling. Increasing anthropogenic Cd loads would necessary lead to increasing Cd-bioaccumulation in the plankton communities, and then in marine resources. As a consequence, Cd levels in fish of the NW African upwelling system should be monitored in the future. Note that there is also a potential impact of phosphate industry releases of Cd in Mauritania and Senegal which has not been accounted for in this study.

\section{Conclusion}

In this work, the dispersion signatures of natural and anthropogenic Cd loads to the coastal NW African upwelling were compared using a lagrangian approach based upon a physicalbiogeochemical hindcast. Our physical-biogeochemical simulation proved its ability to reproduce observed patterns of ocean circulation and plankton production. Wind-induced upwelling of intermediate waters and phosphate industry effluents were considered to be the main Cd sources to the coastal region. Despite the uncertainty of Cd sources estimated from scarse observations available in the literature, our modeling study shows that anthropogenic $\mathrm{Cd}$ is at least of the same order of magnitude than the natural upwelled $\mathrm{Cd}$ in the Moroccan upwelling. Good overall agreement with observed Cd levels found in mollusc and fishes gives us confidence in those results. Nevertheless, another explanation for a southward gradient in Cd levels, involving a lower Cd bioavailability linked to salinity in the Moroccan region, remains possible. This would temperate the effect of anthropogenic Cd inputs.

The biotic-abiotic processes explaining the distribution of Cd-uptake were elucidated. Advection processes are hypothesized to limit primary productivity in the Moroccan compared to the Senegalo-Mauritanian upwelling, and thus Cd-uptake and bioaccumulation from the upwelling source. In a likely manner, the decoupling between offshore transport and coastal primary production is a key factor controlling anthropogenic Cd-uptake: the offshore transport of anthropogenic Cd loads depends on both the event scale variability of filament activity and the geostrophic circulation of the Canary Current. However, Cd-bioaccumulation appears rather controlled by the injection of nutrients due to coastal upwelling as an expression of the role of integrator played by zooplankton. Nearshore mesoscale recirculations probably potentialize Cduptake and bioaccumulation in specific coastal areas.

A future development of phosphate industry along the NW African coast could lead to increased Cd levels in fish and molluscs communities. Consequently, we suggest that Cd levels of marine resources should be monitored to avoid any health hazards on human populations. Our Lagrangian approach provide potential estimate of Cd-bioaccumulation in the plankton food chain. More informations on the metal cycles in the coastal ocean should be acquired (James, 2002) to better parameterize the fate of $\mathrm{Cd}$ in marine food webs. 


\section{Acknowledgments}

We are deeply indebted to Olivier Aumont and Bruno Blanke for discussions that helped us to make an efficient use of the PISCES biogeochemical model and the ARIANE Lagrangian tool. We also wish to thank Tristan Le Toullec and computer engineers from the Institut Universitaire Européen de la Mer (IUEM, Brest, France), particularly Emmanuel Taboré, for their technical support. The present work has been funded by the Franco-Moroccan EPURE project (Eléments trace métalliques, Pollution, Upwelling et Ressources - http://anr-epure.net) under the call CEP\&S of the French National Research Agency (ANR). Open boundary conditions for our regional simulation were provided through by the EURO-BASIN project (Contract No. 26493). Numerical simulations were performed using HPC resources from CAPARMOR (CAlcul PARallèle Mutualisé pour l'Océanographie et la Recherche), a cluster hosted at Ifremer (Brest, France).

\section{References}

Allen, J.S., 1973. Upwelling and Coastal Jets in a Continuously Stratified Ocean. Journal of Physical Oceanography 3, 245-257.

Al-Masri, M.S., Amin, Y., Ibrahim, S., Al-Bich, F., 2004. Distribution of some trace metals in Syrian phosphogypsum. Applied Geochemistry 19, 747-753.

Álvarez-Salgado, X.A., Arístegui, J., Barton, E.D., Hansell, D.A., 2007. Contribution of upwelling filaments to offshore carbon export in the subtropical Northeast Atlantic Ocean. Limnology and Oceanography 52, 1287-1292.

Annual Report, Office Chérifien des Phosphates, Maroc, 2012. http://www.ocpgroup.ma/finance/rapports-publies/rapport-annuel.

Arístegui, J., Barton, E.D., Álvarez-Salgado, X.A., Santos, A.M.P., Figueiras, F.G., Kifani, S., Hernández-León, S., Mason, E., Machú, E., Demarcq, H., 2009. Sub-regional ecosystem variability in the Canary Current upwelling. Progress in Oceanography 83, 33-48.

Arístegui, J., Barton, E.D., Tett, P., Montero, M.F., García-Muñoz, M., Basterretxea, G., Cussatlegras, A.-S., Ojeda, A., de Armas, D., 2004. Variability in plankton community structure, metabolism, and vertical carbon fluxes along an upwelling filament (Cape Juby, NW Africa). Progress in Oceanography 62, 95-113.

Aumont, O., Bopp, L., 2006. Globalizing results from ocean in situ iron fertilization studies. Global Biogeochemical Cycles 20, GB2017.

Aumont, O., Bopp, L., Schulz, M., 2008. What does temporal variability in aeolian dust deposition contribute to sea-surface iron and chlorophyll distributions? Geophysical Research Letters 35.

Aumont, O., Maier-Reimer, E., Blain, S., Monfray, P., 2003. An ecosystem model of the global ocean including Fe, Si, P colimitations. Global Biogeochemical Cycles 17.

Banaoui, A., Chiffoleau, J.F., Moukrim, A., Burgeot, T., Kaaya, A., Auger, D., Rozuel, E., 2004. Trace metal distribution in the mussel Perna perna along the Moroccan coast. Marine Pollution Bulletin 48, 385-390. 
Barton, E.D., Arístegui, J., Tett, P., Navarro-Pérez, E., 2004. Variability in the Canary Islands area of filament-eddy exchanges. Progress in Oceanography 62, 71-94.

Barton, E.D., Arıstegui, J., Tett, P., Cantón, M., Garcı-Braun, J., Hernández-León, S., Nykjaer, L., Almeida, C., Almunia, J., Ballesteros, S., 1998. The transition zone of the Canary Current upwelling region. Progress in Oceanography 41, 455-504.

Benbrahim, S., Chafik, A., Chfiri, R., Bouthir, F.Z., Siefeddine, M., Makaoui, A., 2006. Etude des facteurs influençant la répartition géographique et temporelle de la contamination des côtes atlantiques marocaines par les métaux lourds: cas du mercure, du plomb et du cadmium. Marine Life 16, 37-47.

Binet, D., 1988. Rôle possible d'une intensification des alizés sur le changement de répartition des sardines et sardinelles le long de la côte ouest africaine. Aquatic living resources 1, 115-132.

Blanke, B., Arhan, M., Madec, G., Roche, S., 1999. Warm water paths in the equatorial Atlantic as diagnosed with a general circulation model. Journal of Physical Oceanography 29, 2753-2768.

Blanke, B., Penven, P., Roy, C., Chang, N., Kokoszka, F., 2009. Ocean variability over the Agulhas Bank and its dynamical connection with the southern Benguela upwelling system. Journal of Geophysical Research 114.

Blanke, B., Raynaud, S., 1997. Kinematics of the Pacific equatorial undercurrent: An Eulerian and Lagrangian approach from GCM results. Journal of Physical Oceanography 27, 1038-1053.

Blasco, D., Estrada, M., Jones, B., 1980. Relationship between the phytoplankton distribution and composition and the hydrography in the northwest African upwelling region near Cabo Corbeiro. Deep Sea Research Part A. Oceanographic Research Papers 27, 799-821.

Bonhommeau, S., Blanke, B., TréGuier, A.-M., Grima, N., Rivot, E., Vermard, Y., Greiner, E., Le Pape, O., 2009. How fast can the European eel (Anguilla anguilla) larvae cross the Atlantic Ocean? Fisheries Oceanography 18, 371-385.

Boyle, E.A., Sclater, F., Edmond, J.M., 1976. On the marine geochemistry of cadmium. Nature 263, 42-44.

Brochier, T., Mason, E., Moyano, M., Berraho, A., Colas, F., Sangrà, P., Hernández-León, S., Ettahiri, O., Lett, C., 2011. Ichthyoplankton transport from the African coast to the Canary Islands. Journal of Marine Systems 87, 109-122.

Brumsack, H.-J., 2006. The trace metal content of recent organic carbon-rich sediments: Implications for Cretaceous black shale formation. Palaeogeography, Palaeoclimatology, Palaeoecology 232, 344-361.

Bryan, G.W., 1984. Pollution due to heavy metals and their compounds, Kinne O. ed, Marine Ecology. John Wiley \& Sons, Chichester.

Carr, M.E., 2001. Estimation of potential productivity in Eastern Boundary Currents using remote sensing. Deep Sea Research Part II: Topical Studies in Oceanography 49, 59-80.

Carr, M.E., Kearns, E.J., 2003. Production regimes in four Eastern Boundary Current systems. Deep Sea Research Part II: Topical Studies in Oceanography 50, 3199-3221.

Chafik, A., Cheggour, M., Cossa, D., Sifeddine, S.B.M., 2001. Quality of Moroccan Atlantic coastal waters: water monitoring and mussel watching. Aquatic Living Resources 14, 239-249.

Cheggour, M., Langston, W.J., Chafik, A., Texier, H., Idrissi, H., Boumezzough, A., 1999. 
Phosphate industry discharges and their impact on metal contamination and intertidal macrobenthos: Jorf Lasfar and Safi coastlines (morocco). Toxicological \& Environmental Chemistry 70, 159-179.

Chelton, D.B., Deszoeke, R.A., Schlax, M.G., El Naggar, K., Siwertz, N., 1998. Geographical variability of the first baroclinic Rossby radius of deformation. Journal of Physical Oceanography 28, 433-460.

Comans, R.N.J., Van Dijk, C.P.J., 1988. Role of complexation processes in cadmium mobilization during estuarine mixing. Nature 336, 151-154.

Commission of the European Communities, 2006. Setting Maximum Levels for certain Contaminants in Foodstuffs. Official Journal of the European Union L364, 5-24.

Debreu, L., Marchesiello, P., Penven, P., Cambon, G., 2012. Two-way nesting in split-explicit ocean models: Algorithms, implementation and validation. Ocean Modelling 49-50, 1-21.

Delgadillo-Hinojosa, F., Macias-Zamora, J.V., Segovia-Zavala, J.A., Torres-Valdés, S., 2001. Cadmium enrichment in the Gulf of California. Marine Chemistry 75, 109-122.

Drinkwater, K.F., Beaugrand, G., Kaeriyama, M., Kim, S., Ottersen, G., Perry, R.I., Pörtner, H.-O., Polovina, J.J., Takasuka, A., 2010. On the processes linking climate to ecosystem changes. Journal of Marine Systems 79, 374-388.

Duce, R.A., Liss, P.S., Merrill, J.T., Atlas, E.L., Buat-Menard, P., Hicks, B.B., Miller, J.M., Prospero, J.M., Arimoto, R., Church, T.M., Ellis, W., Galloway, J.N., Hansen, L., Jickells, T.D., Knap, A.H., Reinhardt, K.H., Schneider, B., Soudine, A., Tokos, J.J., Tsunogai, S., Wollast, R., Zhou, M., 1991. The atmospheric input of trace species to the world ocean. Global Biogeochemical Cycles 5, 193-259.

Dufois, F., Penven, P., Peter Whittle, C., Veitch, J., 2012. On the warm nearshore bias in Pathfinder monthly SST products over Eastern Boundary Upwelling Systems. Ocean Modelling 47, 113-118.

Echevin, V., Aumont, O., Ledesma, J., Flores, G., 2008. The seasonal cycle of surface chlorophyll in the Peruvian upwelling system: A modelling study. Progress in Oceanography 79, 167-176.

Edmond, J.M., Spivack, A., Grant, B.C., Ming-Hui, H., Sung, C., Zeng Xiushau, C., 1985. Chemical dynamics of the Changjiang estuary. Continental Shelf Research 4, 17-36.

El Morhit, M., Belghity, D., El Morhit, A., 2013. Contamination métallique de Pagellus acarne, Sardina pilchardus et Diplodus vulgaris de la côte atlantique sud (Maroc). Larhyss Journal 14, 131148.

Finkel, Z.V., Quigg, A.S., Chiampi, R.K., Schofield, O.E., Falkowski, P.G., 2007. Phylogenetic diversity in cadmium: phosphorus ratio regulation by marine phytoplankton. Limnology and Oceanography 52, 1131-1138.

Fischer, G., Karakas, G., Blaas, M., Ratmeyer, V., Nowald, N., Schlitzer, R., Helmke, P., Davenport, R., Donner, B., Neuer, S., Wefer, G., 2009. Mineral ballast and particle settling rates in the coastal upwelling system off NW Africa and the South Atlantic. International Journal of Earth Sciences 98, 281-298.

Fleming, L.E., Broad, K., Clement, A., Dewailly, E., Elmir, S., Knap, A., Pomponi, S.A., Smith, S., Solo Gabriele, H., Walsh, P., 2006. Oceans and human health: Emerging public health risks in the marine environment. Marine Pollution Bulletin 53, 545-560.

Fréon, P., 2009. Eastern Boundary Upwelling Ecosystems: Integrative and comparative approaches. 
Progress in Oceanography 83, 1-14.

García-Muñoz, M., Arístegui, J., Pelegrí, J.L., Antoranz, A., Ojeda, A., Torres, M., 2005. Exchange of carbon by an upwelling filament off Cape Ghir (NW Africa). Journal of Marine Systems 54, 8395.

Gaudry, A., Zeroual, S., Gaie-Levrel, F., Moskura, M., Boujrhal, F.-Z., El Moursli, R.C., Guessous, A., Mouradi, A., Givernaud, T., Delmas, R., 2007. Heavy Metals Pollution of the Atlantic Marine Environment by the Moroccan Phosphate Industry, as Observed through their Bioaccumulation in Ulva Lactuca. Water, Air, and Soil Pollution 178, 267-285.

Gelado-Caballero, M.D., López-García, P., Prieto, S., Patey, M.D., Collado, C., Hérnández-Brito, J.J., 2012. Long-term aerosol measurements in Gran Canaria, Canary Islands: Particle concentration, sources and elemental composition. Journal of Geophysical Research 117.

Gobeil, C., Silverberg, N., Sundby, B., Cossa, D., 1987. Cadmium diagenesis in Laurentian Trough sediments. Geochimica et Cosmochimica Acta 51, 589-596.

Gorgues, T., Menkes, C., Slemons, L., Aumont, O., Dandonneau, Y., Radenac, M.-H., Alvain, S., Moulin, C., 2010. Revisiting the La Niña 1998 phytoplankton blooms in the equatorial Pacific. Deep Sea Research Part I: Oceanographic Research Papers 57, 567-576.

Gruber, G.A., 2012. Phosphorus and Phosphates, Handbook of Industrial Chemistry and Biotechnology. Springer US.

Guieu, C., Loÿe-Pilot, M.-D., Benyahya, L., Dufour, A., 2010. Spatial variability of atmospheric fluxes of metals (Al, Fe, Cd, Zn and $\mathrm{Pb}$ ) and phosphorus over the whole Mediterranean from a oneyear monitoring experiment: Biogeochemical implications. Marine Chemistry 120, 164-178.

Herbland, A., Le Borgne, R., Voituriez, B., 1973. Production primaire, secondaire et regeneration des sels nutritifs dans l'upwelling de Mauritanie. Documents Scientifiques, Centre de Recherches Océanographiques, Abidjan 4, 1-75.

Hernández-Guerra, A., Fraile-Nuez, E., López-Laatzen, F., Martínez, A., Parrilla, G., Vélez-Belchí, P., 2005. Canary Current and North Equatorial Current from an inverse box model. Journal of Geophysical Research 110.

Horner, T.J., Lee, R.B.Y., Henderson, G.M., Rickaby, R.E.M., 2013. Nonspecific uptake and homeostasis drive the oceanic cadmium cycle. Proceedings of the National Academy of Sciences 110, 2500-2505.

James, I.D., 2002. Modelling pollution dispersion, the ecosystem and water quality in coastal waters: a review. Environmental Modelling \& Software 17, 363-385.

José, Y.S., Aumont, O., Machu, E., Penven, P., Moloney, C.L., Maury, O., 2014. Influence of mesoscale eddies on biological production in the Mozambique Channel: Several contrasted examples from a coupled ocean-biogeochemistry model. Deep Sea Research Part II: Topical Studies in Oceanography 100, 79-93.

Kennish, M.J., 1997. Practical Handbook of Estuarine and Marine Pollution. CRC Press, Boca Raton, FL.

Kostianoy, A.G., Zatsepin, A.G., 1996. The West African coastal upwelling filaments and crossfrontal water exchange conditioned by them. Journal of Marine Systems 7, 349-359.

Lachkar, Z., Gruber, N., 2011. What controls biological production in coastal upwelling systems? Insights from a comparative modeling study. Biogeosciences 8, 2961-2976. 
Lane, T.W., Saito, M.A., George, G.N., Pickering, I.J., Prince, R.C., Morel, F.M.M., 2005. Biochemistry: A cadmium enzyme from a marine diatom. Nature 435, 42.

Lathuilière, C., Echevin, V., Lévy, M., 2008. Seasonal and intraseasonal surface chlorophyll-a variability along the northwest African coast. Journal of Geophysical Research 113.

Lozano, G., Brito, A., Hardisson, A., Gutiérrez, Á., González-Weller, D., Lozano, I.J., 2009. Content of Lead and Cadmium in Barred Hogfish, Bodianus scrofa, Island Grouper, Mycteroperca fusca, and Portuguese Dogfish, Centroscymnus coelolepis, from Canary Islands, Spain. Bulletin of Environmental Contamination and Toxicology 83, 591-594.

Lumpkin, R., Johnson, G.C., 2013. Global ocean surface velocities from drifters: Mean, variance, El Niño-Southern Oscillation response, and seasonal cycle: Global Ocean Surface Velocities. Journal of Geophysical Research: Oceans 118, 2992-3006.

Maanan, M., 2007. Biomonitoring of heavy metals usingMytilus galloprovincialis in Safi coastal waters, Morocco. Environmental Toxicology 22, 525-531.

Maanan, M., 2008. Heavy metal concentrations in marine molluscs from the Moroccan coastal region. Environmental Pollution 153, 176-183.

Machín, F., Hernández-Guerra, A., Pelegrí, J.L., 2006. Mass fluxes in the Canary Basin. Progress in Oceanography 70, 416-447.

Machu, E., Ettahiri, O., Kifani, S., Benazzouz, A., Makaoui, A., Demarcq, H., 2009. Environmental control of the recruitment of sardines ( Sardina pilchardus ) over the western Saharan shelf between 1995 and 2002: a coupled physical/biogeochemical modelling experiment. Fisheries Oceanography 18, 287-300.

Marchesiello, P., Estrade, P., 2009. Eddy activity and mixing in upwelling systems: a comparative study of Northwest Africa and California regions. International Journal of Earth Sciences 98, 299308.

Marchesiello, P., McWilliams, J.C., Shchepetkin, A., 2003. Equilibrium structure and dynamics of the California Current System. Journal of Physical Oceanography 33, 753-783.

Margalef, R., 1978. Phytoplankton communities in upwelling areas. The example of NW Africa. Oecologia aquatica 3.

Martínez, M.L., Intralawan, A., Vázquez, G., Pérez-Maqueo, O., Sutton, P., Landgrave, R., 2007. The coasts of our world: Ecological, economic and social importance. Ecological Economics 63, 254-272.

Mason, E., Colas, F., Molemaker, J., Shchepetkin, A.F., Troupin, C., McWilliams, J.C., Sangrà, P., 2011. Seasonal variability of the Canary Current: A numerical study. Journal of Geophysical Research 116.

Mason, E., Colas, F., Pelegrí, J.L., 2012. A Lagrangian study tracing water parcel origins in the Canary Upwelling System. Scientia Marina 76, 79-94.

Metrohm Documentation, 2014. Determination of total phosphate in phosphoric acid and phosphate fertilizers with 859 Titrotherm. Application Bulletin Metrohm 314e.

Minas, H.J., Codispoti, L.A., Dugdame, R.C., 1982. Nutrients and primary production in the upwelling region off Northwest Africa. Rapp. Pv Reun.-Cons. Int. Explor. Mer 180, 148-183.

Mittelstaedt, E., 1983. The upwelling area off Northwest Africa-a description of phenomena 
related to coastal upwelling. Progress in Oceanography 12, 307-331.

Mittelstaedt, E., 1991. The ocean boundary along the northwest African coast: Circulation and oceanographic properties at the sea surface. Progress in Oceanography 26, 307-355.

Morel, F.M.M., Price, N.M., 2003. The Biogeochemical Cycles of Trace Metals in the Oceans. Science 300, 944-947.

Moustaid, K., Nasser, B., Baudrimont, I., Anane, R., El Idrissi, M., Bouzidi, A., Creppy, E.E., 2005. Évaluation comparée de la toxicité des moules (Mytilus galloprovincialis) de deux sites du littoral atlantique marocain sur des souris. Comptes Rendus Biologies 328, 281-289.

Nave, S., Freitas, P., Abrantes, F., 2001. Coastal upwelling in the Canary Island region: spatial variability reflected by the surface sediment diatom record. Marine Micropaleontology 42, 1-23.

Park, H., Song, B., Morel, F.M.M., 2007. Diversity of the cadmium-containing carbonic anhydrase in marine diatoms and natural waters. Environmental Microbiology 9, 403-413.

Parry, M.L., Canziani, O.F., Palutikof, J.P., van der Linden, P.J., Hanson, C.E., 2007. IPCC, 2007: Climate Change 2007: Impacts, Adaptation and Vulnerability. Contribution of Working Group II to the Fourth Assessment Report of the Intergovernmental Panel on Climate Change. Cambridge University Press, Eds., Cambridge, UK.

Pelegrí, J.L., Marrero-Díaz, A., Ratsimandresy, A., Antoranz, A., Cisneros-Aguirre, J., Gordo, C., Grisolía, D., Hernández-Guerra, A., Láiz, I., Martínez, A., Parrilla, G., Pérez-Rodríguez, P., Rodríguez-Santana, A., Sangrà, P., 2005. Hydrographic cruises off northwest Africa: the Canary Current and the Cape Ghir region. Journal of Marine Systems 54, 39-63.

Pous, S., Feunteun, E., Ellien, C., 2010. Investigation of tropical eel spawning area in the SouthWestern Indian Ocean: Influence of the oceanic circulation. Progress in Oceanography 86, 396-413.

Ripperger, S., Rehkämper, M., Porcelli, D., Halliday, A.N., 2007. Cadmium isotope fractionation in seawater - A signature of biological activity. Earth and Planetary Science Letters 261, 670-684.

Romeo, M., Siau, Y., Sidoumou, Z., Gnassia-Barelli, M., 1999. Heavy metal distribution in different fish species from the Mauritania coast. Science of the Total Environment 232, 169-175.

Romeo, M., Sidoumou, Z., Gnassia-Barelli, M., 2000. Heavy Metals in Various Molluscs from the Mauritanian Coast. Bulletin of Environmental Contamination and Toxicology 65, 269-276.

Rossi, N., Jamet, J.-. ., 2008. In situ heavy metals (copper, lead and cadmium) in different plankton compartments and suspended particulate matter in two coupled Mediterranean coastal ecosystems (Toulon Bay, France). Marine Pollution Bulletin 56, 1862-1870.

Ruangsomboon, S., Wongrat, L., 2006. Bioaccumulation of cadmium in an experimental aquatic food chain involving phytoplankton (Chlorella vulgaris), zooplankton (Moina macrocopa), and the predatory catfish Clarias macrocephalus $\times$ C. gariepinus. Aquatic Toxicology 78, 15-20.

Saha, S., Moorthi, S., Pan, H.-L., Wu, X., Wang, J., Nadiga, S., Tripp, P., Kistler, R., Woollen, J., Behringer, D., 2010. The NCEP climate forecast system reanalysis. Bulletin of the American Meteorological Society 91.

Sala, I., Caldeira, R.M.A., Estrada-Allis, S.N., Froufe, E., Couvelard, X., 2013. Lagrangian transport pathways in the northeast Atlantic and their environmental impact. Limnology \& Oceanography: Fluids \& Environments 3, 40-60.

Shahidul Islam, M., Tanaka, M., 2004. Impacts of pollution on coastal and marine ecosystems 
including coastal and marine fisheries and approach for management: a review and synthesis. Marine Pollution Bulletin 48, 624-649.

Shchepetkin, A.F., McWilliams, J.C., 2005. The regional oceanic modeling system (ROMS): a splitexplicit, free-surface, topography-following-coordinate oceanic model. Ocean Modelling 9, 347404.

Sidoumou, Z., 1991. Qualité des eaux du littoral mauritanien: étude des métaux traces chez deux mollusques bivalves Venus verrucosa et Donax rugosus. PhD Thesis, Université de Nice - SophiaAntipolis.

Sidoumou, Z., Gnassia-Barelli, M., Siau, Y., Morton, V., Romeo, M., 2005. Distribution and Concentration of Trace Metals in Tissues of Different Fish Species from the Atlantic Coast of Western Africa. Bulletin of Environmental Contamination and Toxicology 74, 988-995.

Sidoumou, Z., Gnassia-Barelli, M., Siau, Y., Morton, V., Romeo, M., 2006. Heavy metal concentrations in molluscs from the Senegal coast. Environment International 32, 384-387.

Sidoumou, Z., Gnassia-Barelli, M., Siau, Y., Romeo, M., 1999. Study of heavy metals in two species of molluscs from the Mauritania coast, Crassostrea gigas and Perna perna. Journal de recherche oceanographique. Paris 24, 13-18.

Sidoumou, Z., Romeo, M., Gnassia-Barelli, M., Nguyen, P., Caruba, R., 1992. Détermination de la qualité des eaux du littoral mauritanien par la mesure des métaux traces chez les mollusques Donax rugosus et Venus verrucosa. Hydroécologie appliquée 4, 33-41.

Stramma, L., 1984. Potential vorticity and volume transport in the eastern North Atlantic from two long CTD sections. Deutsche Hydrografische Zeitschrift 37, 147-155.

Stramma, L., Siedler, G., 1988. Seasonal changes in the North Atlantic subtropical gyre. Journal of Geophysical Research: Oceans 93, 8111-8118.

Sunda, W.G., 2012. Feedback Interactions between Trace Metal Nutrients and Phytoplankton in the Ocean. Frontiers in Microbiology 3.

Sunda, W.G., Huntsman, S.A., 1997. Interrelated influence of iron, light and cell size on marine phytoplankton growth. Nature 390, 389-392.

Tepe, Y., Türkmen, M., Türkmen, A., 2008. Assessment of heavy metals in two commercial fish species of four Turkish seas. Environmental Monitoring and Assessment 146, 277-284.

Theodosi, C., Markaki, Z., Tselepides, A., Mihalopoulos, N., 2010. The significance of atmospheric inputs of soluble and particulate major and trace metals to the eastern Mediterranean seawater. Marine Chemistry 120, 154-163.

Troupin, C., Mason, E., Beckers, J.-M., Sangrà, P., 2012. Generation of the Cape Ghir upwelling filament: A numerical study. Ocean Modelling 41, 1-15.

Twining, B.S., Baines, S.B., 2013. The Trace Metal Composition of Marine Phytoplankton. Annual Review of Marine Science 5, 191-215.

Van Camp, L., Nykjaer, L., Mittelstaedt, E., Schlittenhardt, P., 1991. Upwelling and boundary circulation off Northwest Africa as depicted by infrared and visible satellite observations. Progress in Oceanography 26, 357-402.

Wang, W.-X., 2002. Interactions of trace metals and different marine food chains. Marine Ecology Progress Series 243, 295-309. 
Wang, W.-X., Dei, R.C., 2001. Effects of major nutrient additions on metal uptake in phytoplankton. Environmental Pollution 111, 233-240.

Wang, W.-X., Rainbow, P.S., 2008. Comparative approaches to understand metal bioaccumulation in aquatic animals. Comparative Biochemistry and Physiology Part C: Toxicology \& Pharmacology 148, 315-323.

Wooster, W.S., Bakun, A.M.D.R., McLain, D.R., 1976. Seasonal upwelling cycle along eastern boundary of North-Atlantic. Journal of Marine Research 34, 131-141.

Xu, Y., Feng, L., Jeffrey, P.D., Shi, Y., Morel, F.M.M., 2008. Structure and metal exchange in the cadmium carbonic anhydrase of marine diatoms. Nature 452, 56-61.

Yeats, P.A., Westerlund, S., Flegal, A.R., 1995. Cadmium, copper and nickel distributions at four stations in the eastern central and south Atlantic. Marine Chemistry 49, 283-293.

Zenk, W., Klein, B., Schröder, M., 1991. Cape Verde Frontal Zone. Deep Sea Research Part I: Oceanographic Research Papers 38, S505-S530.Allen, J.S., 1973. Upwelling and Coastal Jets in a Continuously Stratified Ocean. Journal of Physical Oceanography 3, 245-257. 

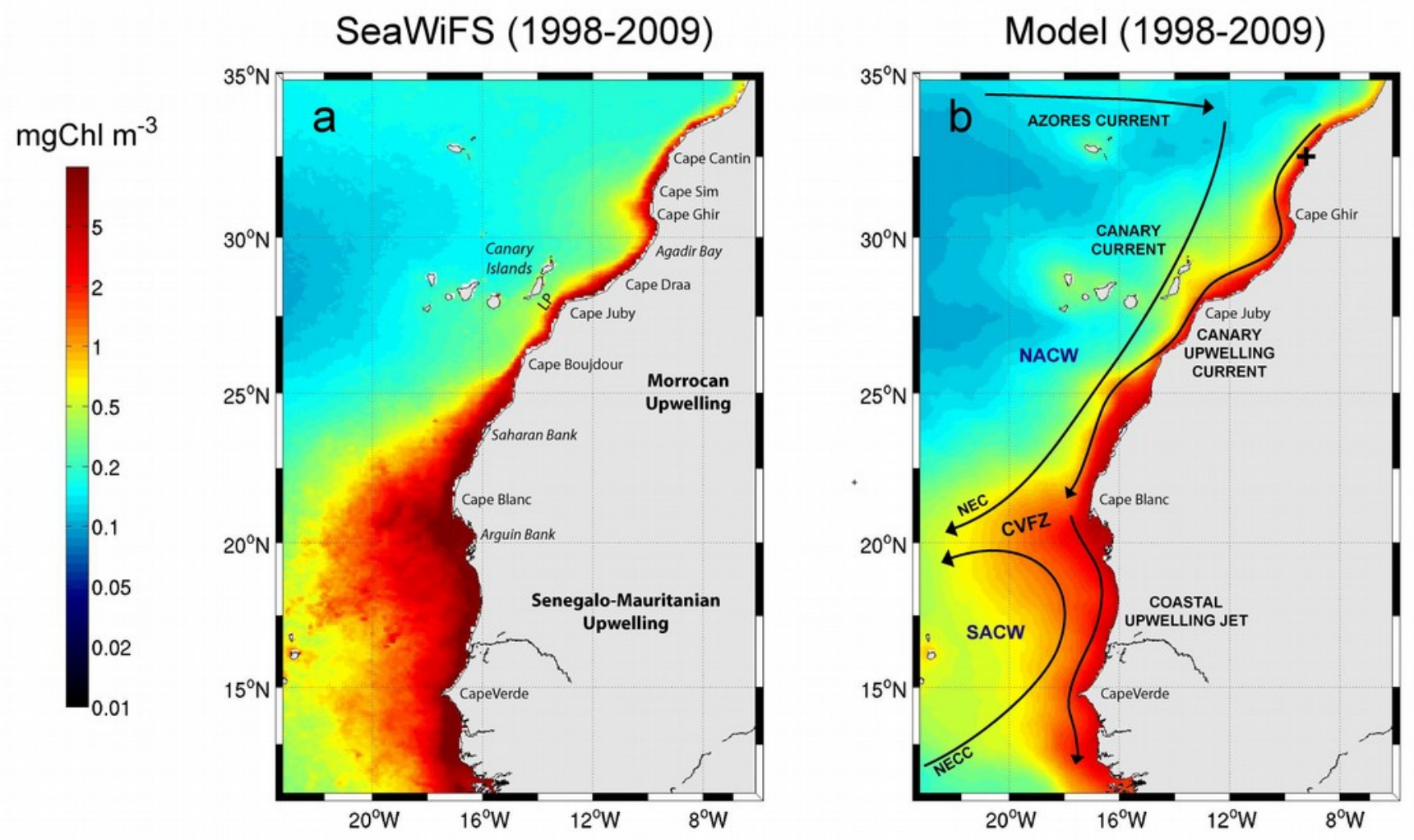

Figure 1. Map of surface chlorophyll concentrations from (a) SeaWiFS and (b) ROMS-PISCES averaged over the period 1998-2009. We indicate major capes, main surface currents and deep water masses over the study area. LP: Lanzarote Passage; NEC: North Equatorial Current; NECC: North Equatorial Countercurrent; CVFZ: Cape Verde Frontal Zone; NACW: North Atlantic Central Water; SACW: South Atlantic Central Water. The black cross indicates the location of the anthropogenic Cd loads. 


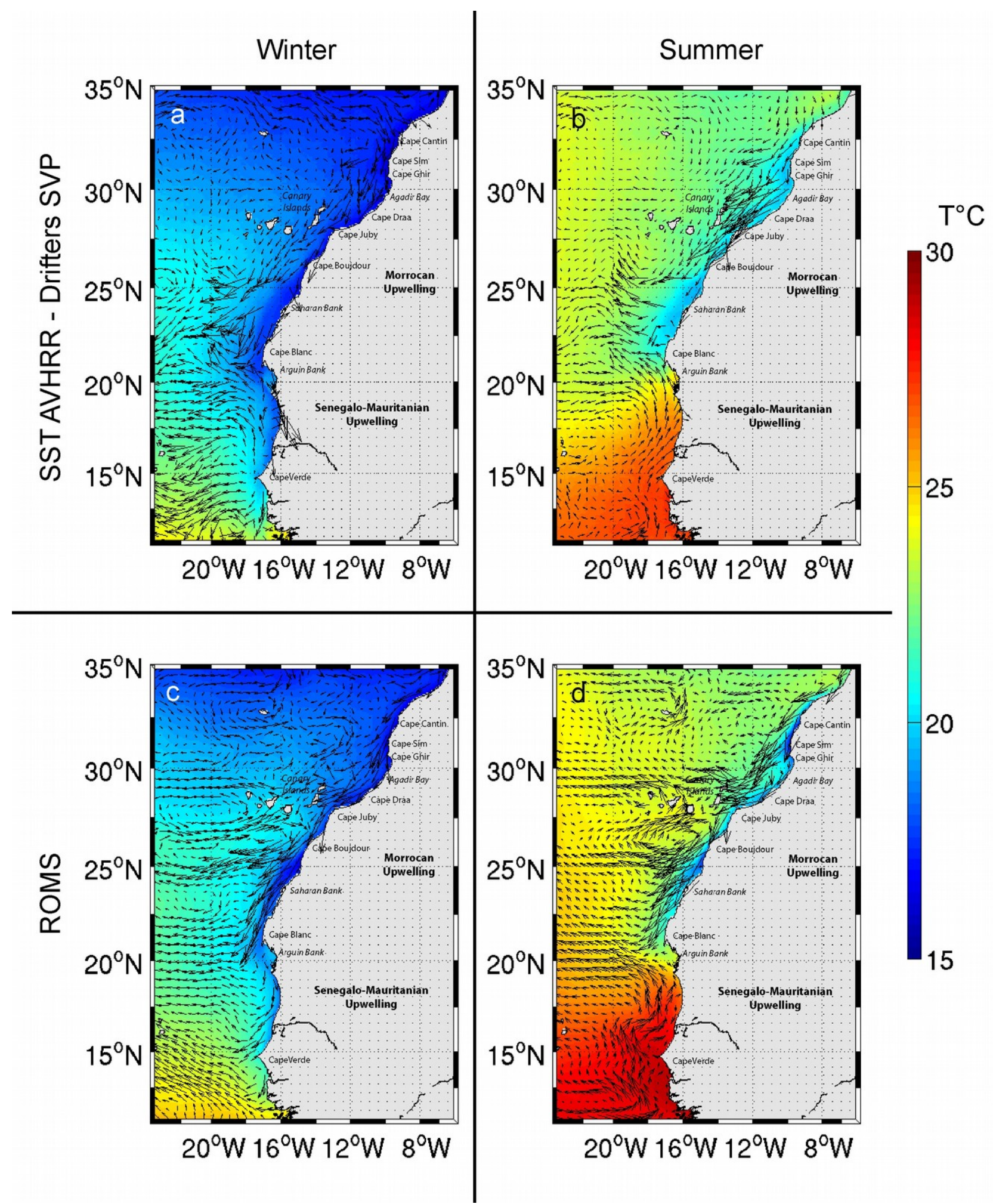

Figure 2. Seasonal climatology of sea surface temperature (SST in background) and near-surface currents (vectors) from AVHRR satellite data (1985-2009) and the Global Drifter Program (1979present, Lumpkin and Johnson, 2013) in (a) winter and (b) summer. Same for ROMS-PISCES in (c) winter and (d) summer. 

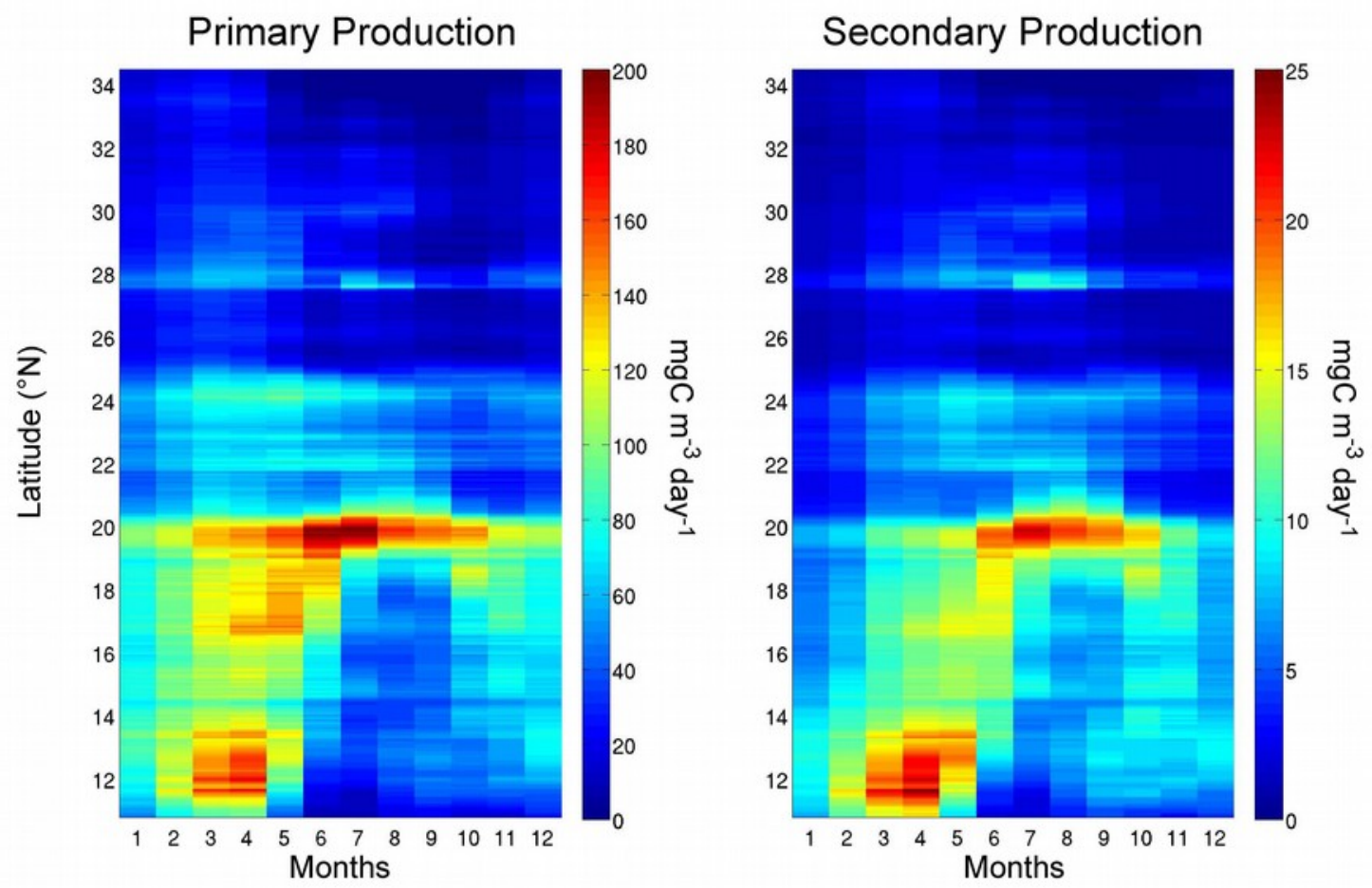

Figure 3. Seasonal climatology of surface primary and secondary production averaged over the 0$200 \mathrm{~km}$ coastal band along the NW African coast $\left(\mathrm{mgC} \mathrm{m}^{-3}\right.$ day $\left.^{-1}\right)$.

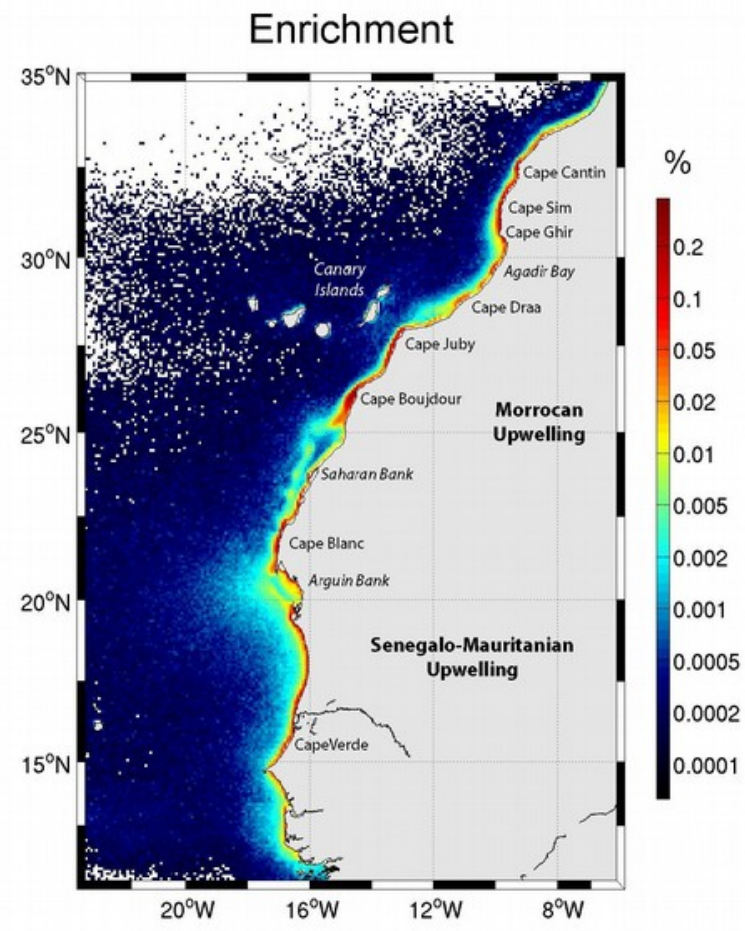

Figure 4. Average enrichment by upwelling (\%, log scale), i.e. number of particles reaching 30m depth after being released between 75 and 300m normalized by the total number of released particles. 

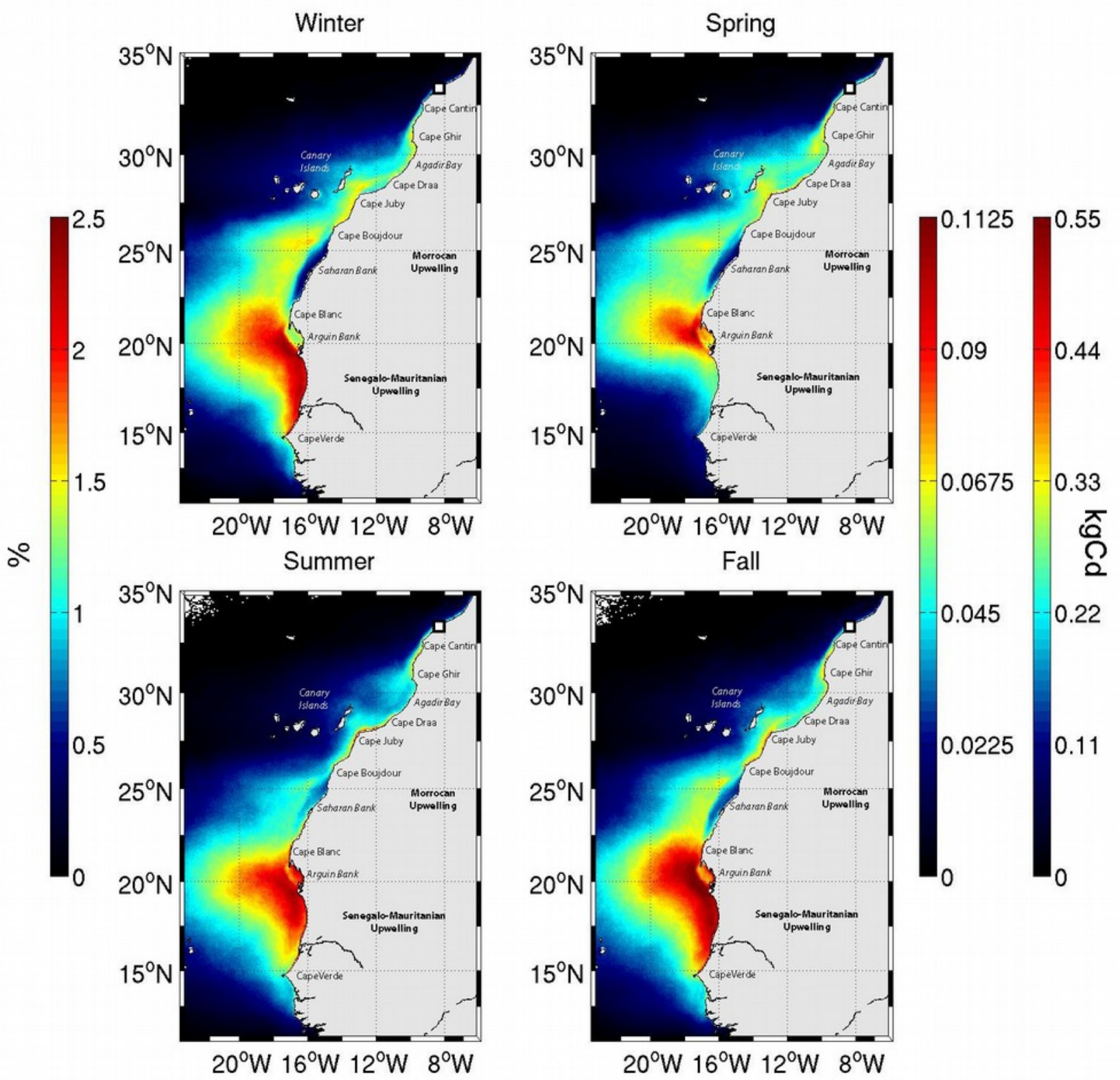

Figure 5. Seasonal climatology of natural Cd-dispersion (\%: left color bar; kgCd: right color bar as described in Figure 6); seasons are defined as successive 3 months periods starting in winter (January to March). 

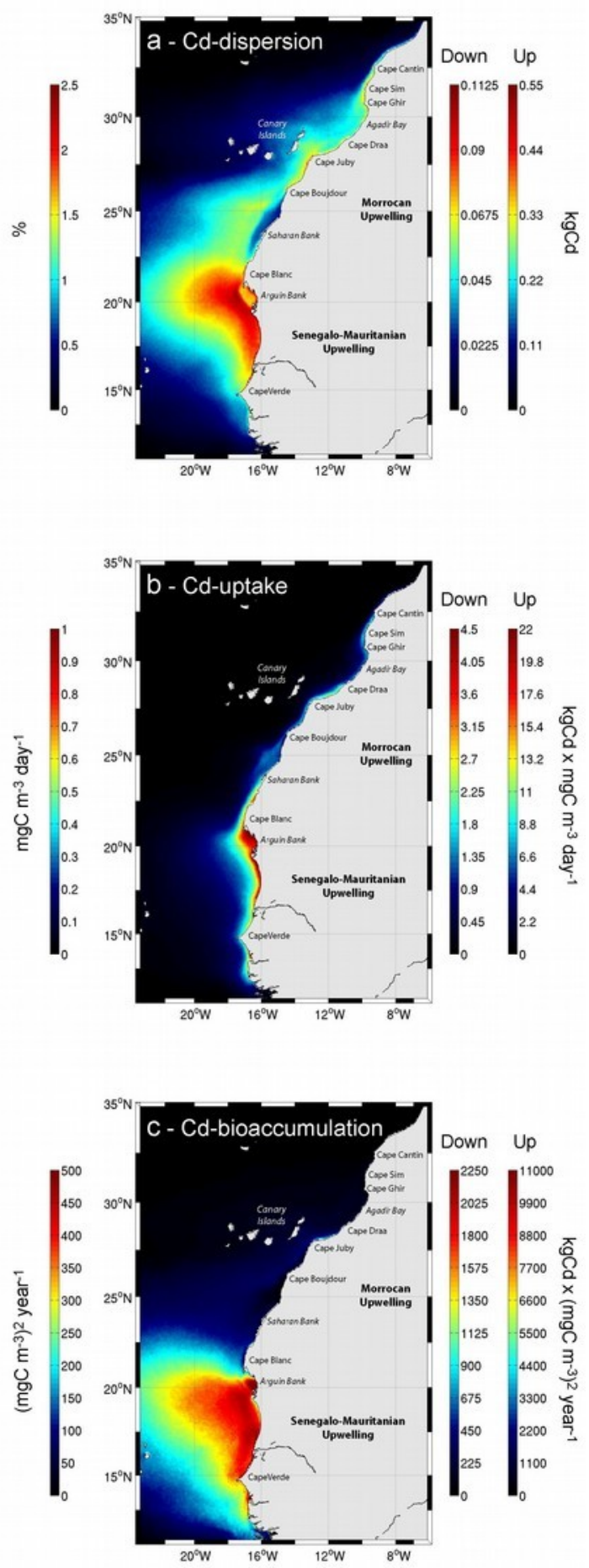

Figure 6. (a) Average dispersion of upwelled Cd-rich water parcels over the two-dimensional "Child" grid (\%, left color bar); (b) Average primary production seen by upwelled Cd-rich water parcels along their trajectory $\left(\mathrm{mgC} \mathrm{m}^{-3} \mathrm{day}^{-1}\right)$; (c) Average Cd-bioaccumulation, i.e. integrated "primary * secondary production" seen by upwelled Cd-rich water parcels along their trajectory ((mgC m$\left.)^{-3}\right)^{2}$ year-1). The right color bars represent a low/high estimation (resp. "Down"/"Up”) of (a) the cadmium mass passing in each grid cell $(\mathrm{kgCd})$, (b) the phytoplankton Cd-uptake (kgCd mgC $\mathrm{m}^{-3}$ day $^{-1}$ ) and (c) the Cd-bioaccumulation $\left(\mathrm{kgCd}\left(\mathrm{mgC} \mathrm{m}^{-3}\right)^{2}\right.$ year $\left.{ }^{-1}\right)$ to be compared to the anthropogenic signature (see Figure 7). 

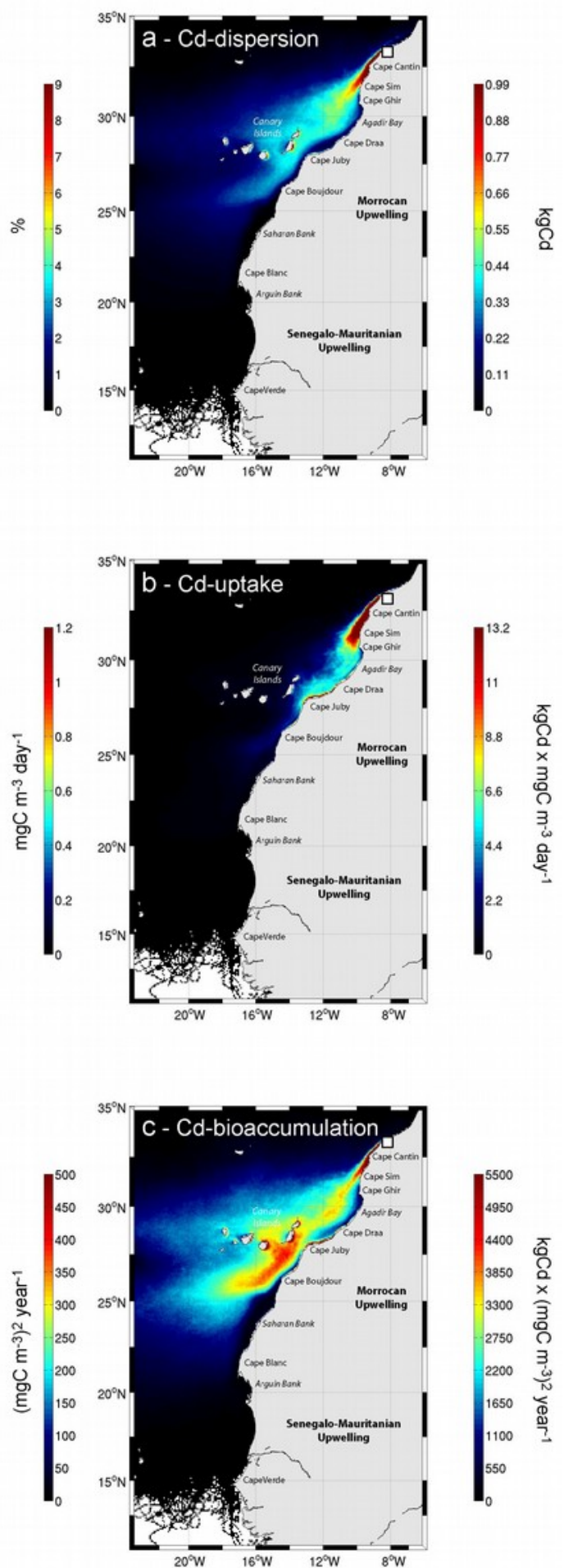

Figure 7. Same as Figure 6 for anthropogenic loads by phosphate industry in the region of Safi/JorfLasfar (Cape Cantin, Morocco; white square). The right color bars represent our estimation of (a) the cadmium mass passing in each grid cell $(\mathrm{kgCd})$, (b) the phytoplankton Cd-uptake (kgCd mgC $\mathrm{m}^{-3}$ day $\left.^{-1}\right)$ and (c) the Cd-bioaccumulation $\left(\mathrm{kgCd}\left(\mathrm{mgC} \mathrm{m}^{-3}\right)^{2}\right.$ year $\left.{ }^{-1}\right)$ to be compared to the natural signature (see Figure 6). 

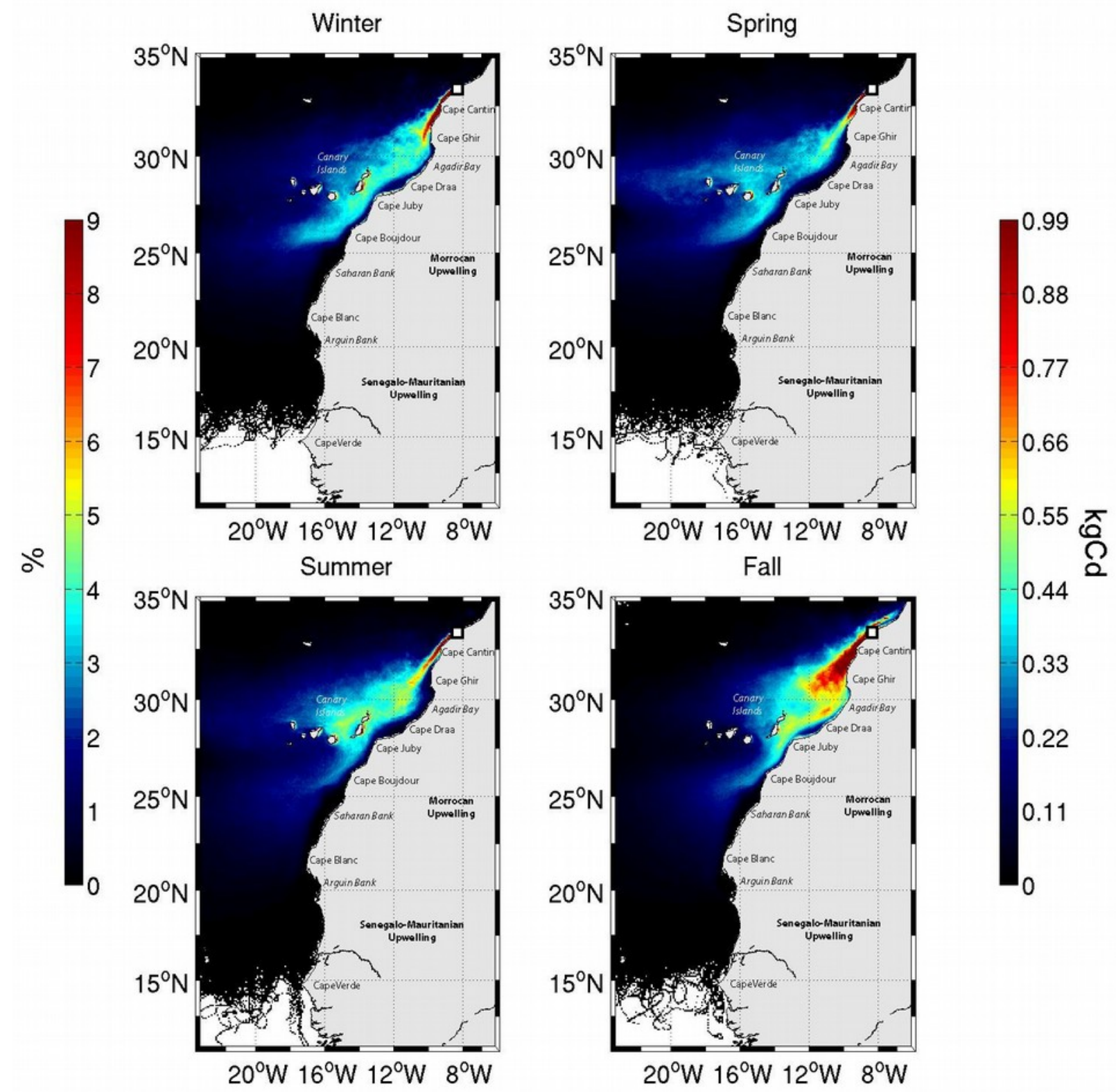

Figure 8. Seasonal climatology of anthropogenic Cd-dispersion (\%: left color bar; kgCd: right color bars as described in Figure 6); seasons are defined as successive 3 months periods starting in winter (January to March). 


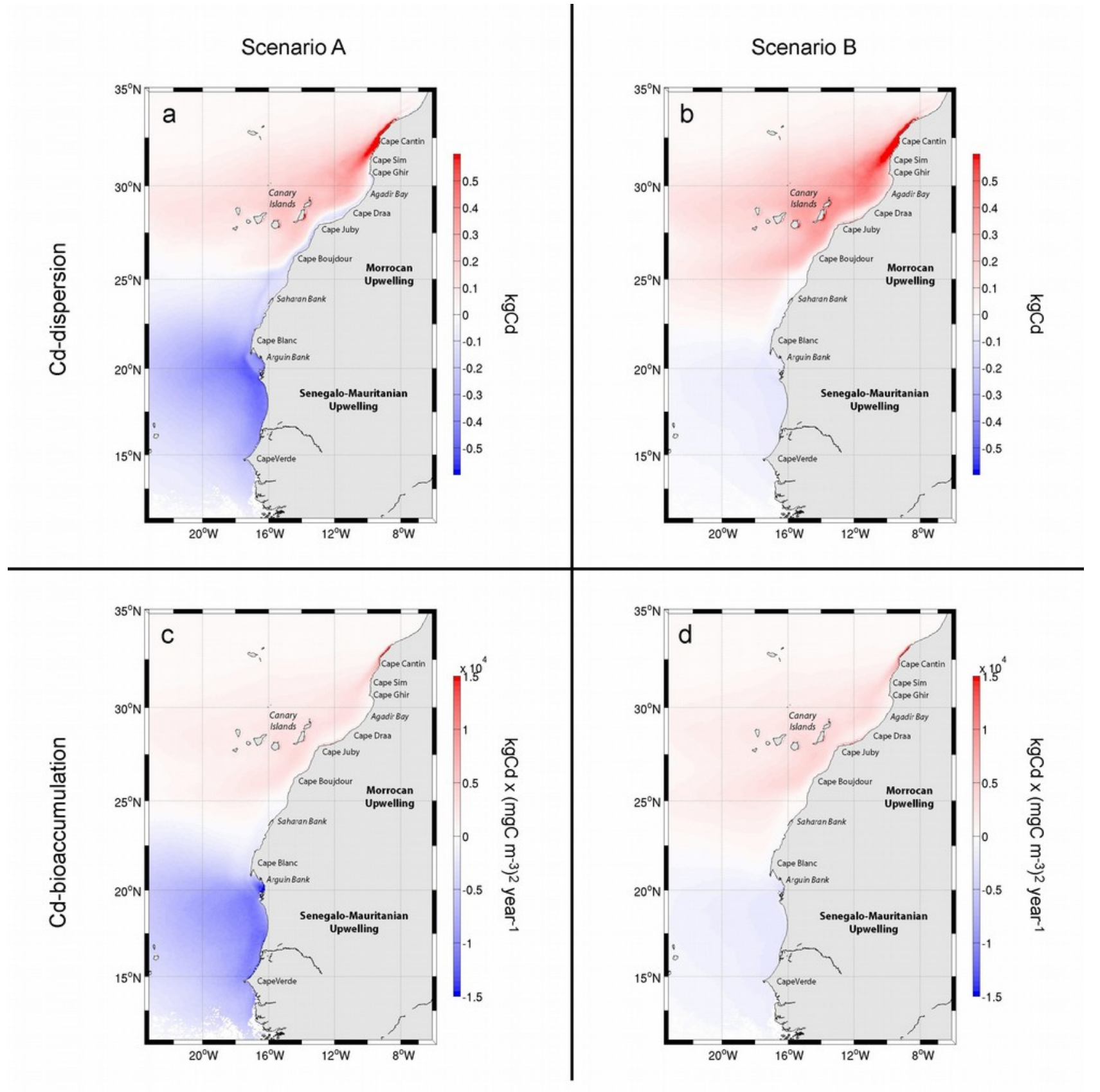

Figure 9. Differences between the anthropogenic and the natural dispersion signatures of Cd-rich water parcels (kgCd) assuming (a) Scenario A and (b) Scenario B of high/low weight attributed to natural loads; the concentration of $\mathrm{Cd}$ in upwelling source waters is taken equal to $0.10 \mu \mathrm{mol} \mathrm{m}^{-3}$ for Scenario A and $0.02 \mu \mathrm{mol} \mathrm{m}{ }^{-3}$ for Scenario B which is the range observed in the eastern central Atlantic (Yeats et al., 1995). Same for the difference of Cd-bioaccumulation ( $\mathrm{kgCd}\left(\mathrm{mgC} \mathrm{m}^{-3}\right)^{2}$ year- $^{-}$ ${ }^{1}$ ) assuming (c) Scenario A and (d) Scenario B. 


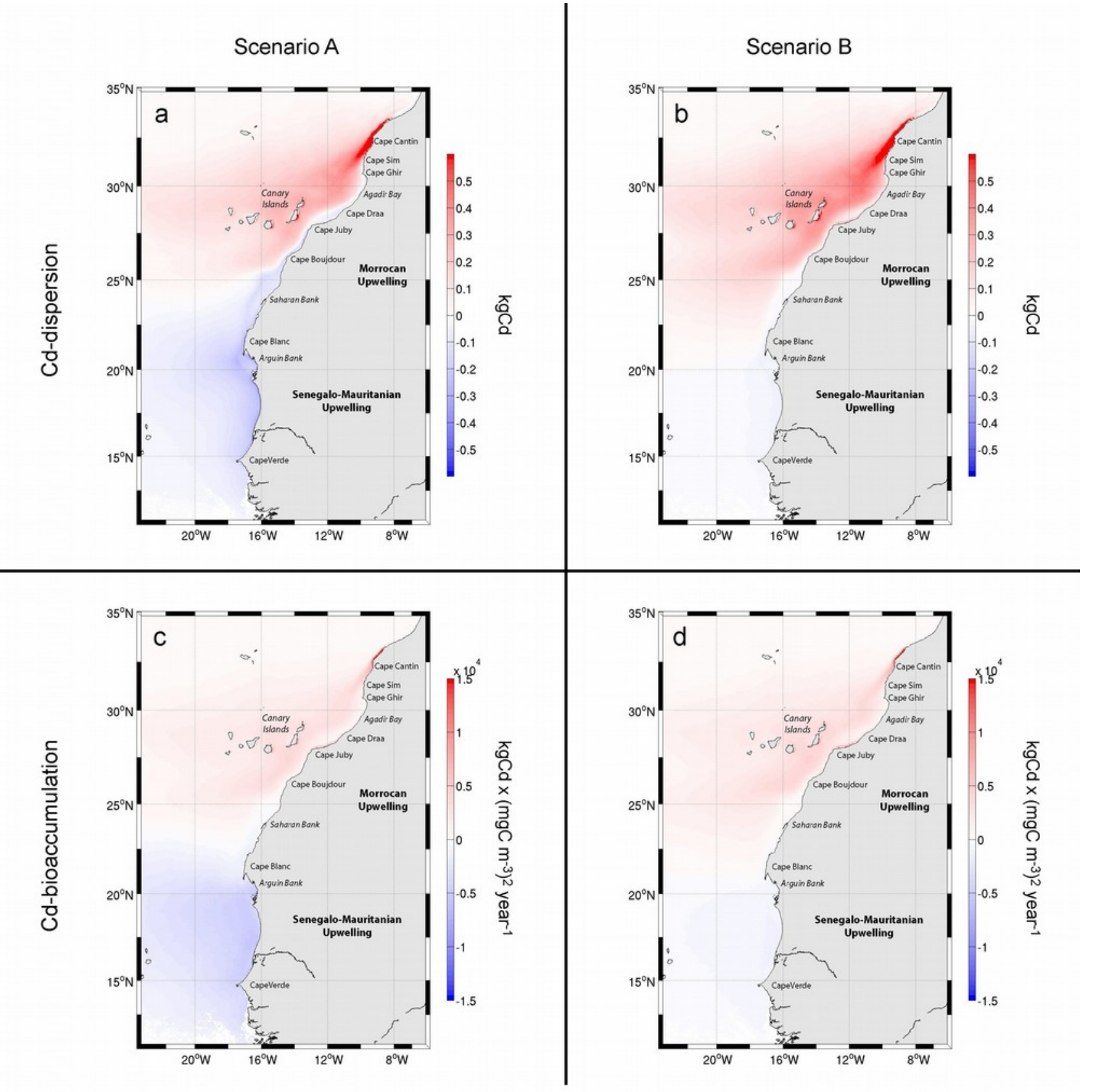

Figure 10. Same as Figure 9 considering a loss of Cd along the path of particles. The along-path loss of $\mathrm{Cd}$ is diagnosed as the cumulated particulate organic carbon export due to sinking, then converted to Cd through successive P:C and Cd:P ratios (see Section 3.4). 


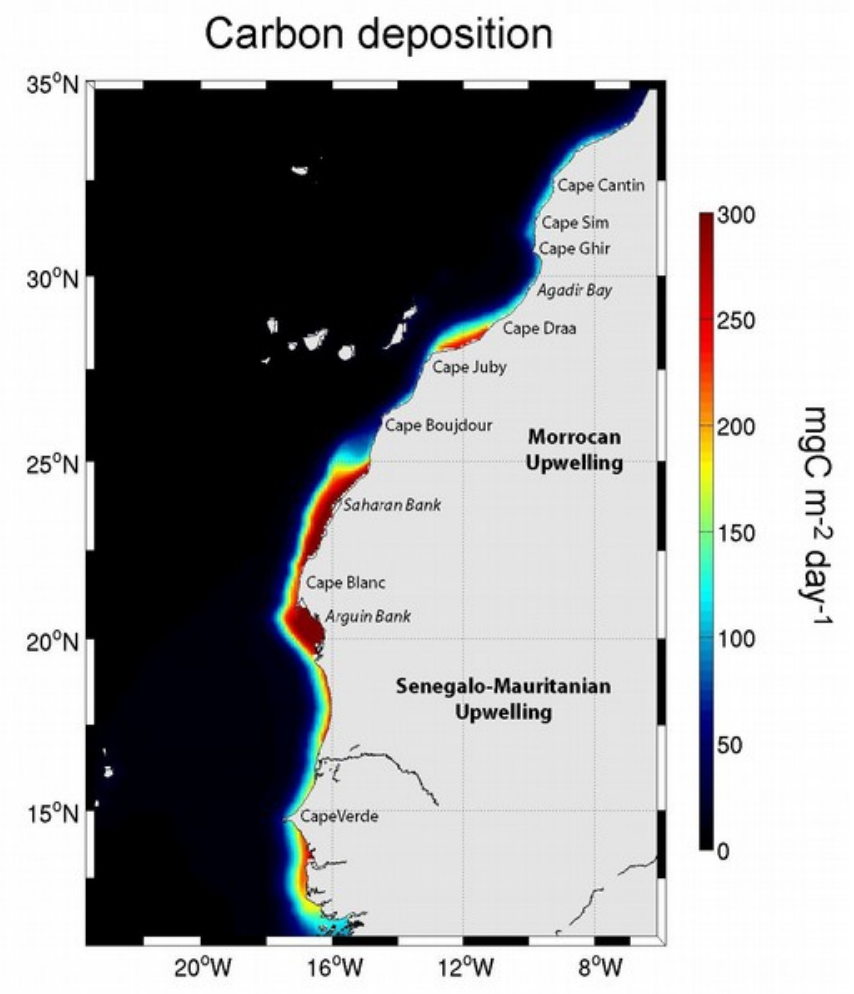

Figure 11. Export at the sea bottom of sinking particulate organic carbon averaged over the simulation period 1980-2009 $\left(\mathrm{mgC} \mathrm{m}^{-2}\right.$ day $\left.^{-1}\right)$.

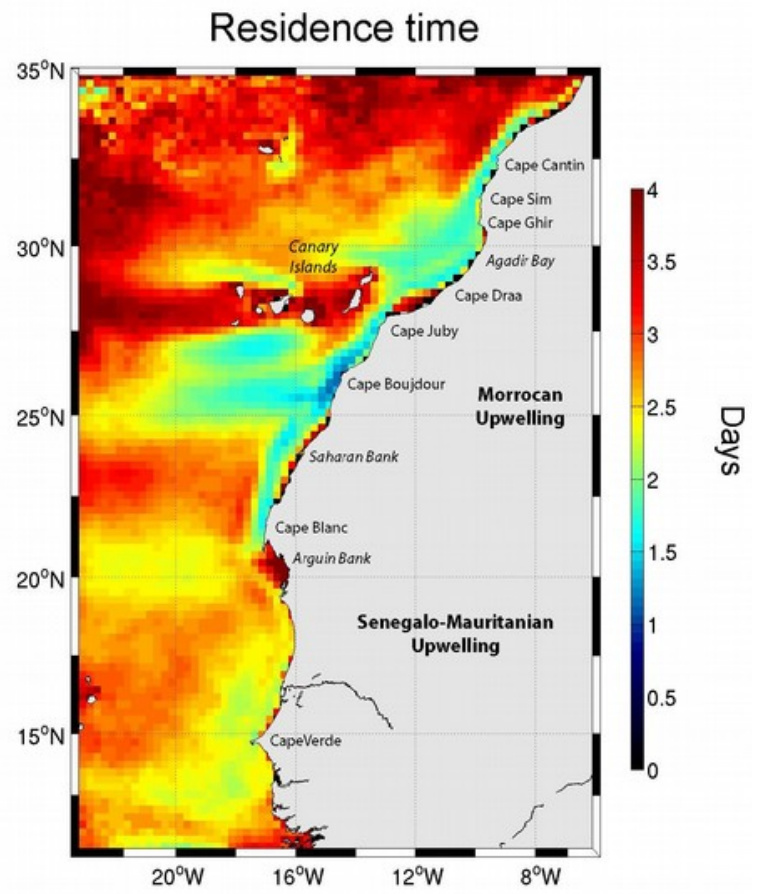

Figure 12. Average residence time of particles (days) passing in each grid cell of the twodimensional "Parent” grid $\left(1 / 4^{\circ}\right)$. 